\title{
Equity Mispricing and Leverage Adjustment Costs
}

\author{
Richard S. Warr, William B. Elliott, Johanna Koëter-Kant, and \\ Özde Öztekin*
}

\begin{abstract}
We find that equity mispricing impacts the speed at which firms adjust to their target leverage (TL) and does so in predictable ways depending on whether the firm is overor underlevered. For example, firms that are above their TL and should therefore issue equity (or retire debt) adjust more rapidly toward their target when their equity is overvalued. However, when a firm is undervalued but needs to reduce leverage, the speed of adjustment is much slower. Our findings support the role of equity mispricing as an important factor that alters the cost of making capital structure adjustments.
\end{abstract}

\section{Introduction}

The trade-off theory of capital structure states that a firm selects an optimal target leverage (TL) ratio that trades off the relative costs and benefits of debt. Empirically, however, it is well documented that firms deviate from their TL ratios and do not rapidly adjust back to their target if they face costs to do so. ${ }^{1}$ Over 25 years ago Myers (1984) noted in his Presidential Address to the American Finance Association (AFA):

If adjustment costs are large, so that some firms take extended excursions away from their targets, then we ought to give less attention to refining our static trade-off stories and relatively more to understanding what

\footnotetext{
*Warr, rswarr@ncsu.edu, Poole College of Management, North Carolina State University, Box 7229, Raleigh, NC 27695; Elliott, wbelliott@utep.edu, Department of Economics and Finance, University of Texas at El Paso, 500 W University Ave, El Paso, TX 79968; Koëter-Kant, jkoeter@feweb.vu.nl, Faculty of Economics and Business Administration, VU University Amsterdam, De Boelelaan 1105, Amsterdam 1081 HV, The Netherlands; and Öztekin, ozde@ fiu.edu, College of Business Administration, Florida International University, 11200 SW 8th St, Miami, FL 33199. We thank Erik Devos, Srini Krishnamurthy, James Upson, Mark Walker, Baozhong Yang (the referee), and seminar participants at North Carolina State University, and the 2009 European Financial Management Association Annual Meeting for many helpful comments. All errors remain our own.

${ }^{1}$ The growing literature that studies the effects of adjustment costs on the speed of adjustment to TL includes works by Hovakimian, Opler, and Titman (2001), Leary and Roberts (2005), Flannery and Rangan (2006), Strebulaev (2007), and Huang and Ritter (2009), among others.
} 
the adjustment costs are, why they are so important, and how rational managers would respond to them.

We find strong empirical evidence for one such adjustment cost, namely the temporary deviation of a firm's share price from its fundamental value and the resulting impact on the cost of equity. If equity is overvalued in the market, the firm's cost of issuing equity is reduced, whereas undervalued equity results in a higher cost of equity. If the cost of issuing equity is altered in this fashion, and if the firm exploits or faces these costs, then the rate at which the firm adjusts toward a target debt ratio will depend on the degree of equity mispricing. While the previous literature has debated the permanence of the market timing effects of mispriced equity, our study models equity mispricing as a factor that impacts the cost of making capital structure adjustments.

We hypothesize that when equity is overvalued in the market (and thus the overall cost to issue equity is low), the firm will adjust more rapidly toward its TL when that adjustment can be achieved by issuing equity. Correspondingly, when the firm's stock is undervalued and issuing equity is relatively expensive, adjustments that call for equity issuance will be made more slowly. The corollary should also exist when the adjustment calls for repurchasing stock. A firm below its TL should issue debt, repurchase equity, or do both through an exchange offer. If equity is undervalued, the cost to repurchase equity is lower, and we expect the firm to move back to its TL more quickly than a firm with overvalued equity in the same situation.

Table 1 graphically presents our hypotheses. In this table, firms are divided into 4 quadrants depending on whether they are above or below their TL and whether they are over- or undervalued. If equity mispricing affects the speed of adjustment, then the speed in the top left quadrant (overlevered and overvalued) will be higher than the speed in the top right quadrant (overlevered and undervalued). Furthermore, the speed in the bottom right quadrant (underlevered and undervalued) will be higher than the speed in the bottom left quadrant (underlevered and overvalued).

TABLE 1

Predictions of the Impact of Equity Mispricing on the Rate of Adjustment to TL Ratios

Table 1 presents the major hypotheses tested. The column headings indicate whether the firm is overvalued or undervalued according to the earnings-based valuation model. The row headings indicate whether the firm is overlevered or underlevered relative to the empirically estimated target leverage (TL). The predicted rate of adjustment to the target is the hypothesized value of $\lambda$ from the equation

(1)

$$
\mathrm{DR}_{t+1}-\mathrm{DR}_{t}=\lambda\left[\mathrm{TL}_{t+1}-\mathrm{DR}_{t}\right]+e_{t+1}
$$

where $\mathrm{DR}_{t+1}$ is the debt-to-assets ratio in period $t+1$ and $\mathrm{TL}_{t+1}$ is the target debt ratio in period $t+1$ obtained using the Fama and French (2002) and Blundell and Bond (1998) approaches for estimating the target book debt ratio (BDR) and target market debt ratio (MDR). Please see Section III.C for details. The distance $\left[\mathrm{TL}_{t+1}-\mathrm{DR}_{t}\right]$ is the total amount that the debt ratio must change to bring the firm back to its target debt ratio. 
To estimate mispricing, we use the equity value as determined by the residual income model scaled by the market price. This approach, developed by RhodesKropf, Robinson, and Viswanathan (2005), separates mispricing effects from growth options. We use 2 versions of the residual income model: 1 that uses forward-looking realized earnings and 1 that uses analyst's forecasted earnings. Any mispricing captured by the forward-looking model could be due to asymmetric information between managers and shareholders or irrationality on the part of shareholders. Mispricing captured by the analyst data model, on the other hand, suggests only investor irrationality. In our study, the root cause of mispricing is not important, as long as managers are aware of the mispricing and use it to the firm's advantage when making capital structure adjustments.

We find that within the context of a firm having a target capital structure, equity mispricing costs have a significant impact on the rate at which firms adjust their capital structure. More specifically, overvalued firms with leverage ratios above their target adjust back toward their target more rapidly than do undervalued firms. The opposite effect is found for firms that are below their target: The overvalued firms adjust more slowly than do the undervalued firms.

This finding is consistent with managers exploiting equity mispricing to time the market. When the cost to issue equity is low (because stock is overvalued), managers exploit this mispricing to the benefit of existing shareholders and more rapidly return to their TL. Likewise, when the firm's equity is undervalued, the firm will adjust more slowly if adjustment calls for equity issuance, as such an issuance would be value-destroying to existing shareholders.

We check the robustness of our results with several additional tests. In the 1st test, we substitute the ex post data used to estimate the equity mispricing with analyst earnings forecasts. This change should reduce any potential endogeneity in our mispricing measure. Using analyst forecasts significantly reduces the size of our sample; however, our results are not qualitatively altered. Our 2nd robustness test examines whether our method is somehow "hard coded" to find a result in favor of the mispricing effect. To do this, we randomize our valuation measure and rerun our tests. We find that our results completely disappear, as we would expect. For our 3rd robustness test, we differentiate between firms with positive cash flow and negative cash flow as do Faulkender, Flannery, Hankins, and Smith (2009), who explicitly examine cash flow effects on adjustment speeds. Consistent with our expectations, firms with negative cash flow that need to raise capital will adjust to their target rapidly when equity is overvalued and the firm is overlevered (in effect, a situation where all the financial planets are aligned in favor of equity issuance). A similar effect is found when firms have a cash surplus and rapidly repurchase equity when their equity is undervalued. The 4th robustness test examines the impact of growth options on the valuation effect and finds that the valuation effect still persists. Finally, we check that our results are robust to both market debt ratios (MDRs) and book debt ratios (BDRs), different methods of estimating TL, the inclusion of zero-debt firms, and subperiod analysis.

The paper proceeds as follows: Section II discusses previous literature and provides the motivation for our study. Section III presents the data. Section IV presents the results and robustness tests, and Section $\mathrm{V}$ concludes. 


\section{Literature Review and Motivation}

\section{A. The Rate of Adjustment to TL}

The dynamic trade-off theory of capital structure states that firms have an optimal target capital structure. If the costs of adjustment were 0 , the firm would have no incentive to deviate from this optimal target, and adjustments would be instantaneous. However, because of market imperfections such as asymmetric information and financing costs (which in part drive discreet and lumpy security issuance), firms may temporarily deviate from their optimal TL. While this phenomenon is documented in other empirical studies, the speed at which reversion to a target occurs remains a topic of debate in the literature.

The standard partial adjustment model measures the rate at which the firm adjusts its debt ratio to a target capital structure. A typical representation of the basic model is

$$
\mathrm{DR}_{t+1}-\mathrm{DR}_{t}=\lambda\left[\mathrm{TL}_{t+1}-\mathrm{DR}_{t}\right]+e_{t+1}
$$

where $\mathrm{DR}_{t+1}$ is the debt-to-assets ratio in period $t+1$, and $\mathrm{TL}_{t+1}$ is the target debt ratio in period $t+1$. The distance $\left[\mathrm{TL}_{t+1}-\mathrm{DR}_{t}\right]$ is the total amount that the debt ratio must change to bring the firm back to its target debt ratio. We refer to this quantity as "DISTANCE." Fama and French (2002) find that firms adjust to target capital structures quite slowly (7\%-18\% annually). Later studies by Leary and Roberts (2005), Alti (2006), Flannery and Rangan (2006), and Lemmon, Roberts, and Zender (2008) suggest that the rate of adjustment is somewhat faster than that reported by Fama and French. For example, using an instrumental approach to estimate TL, Flannery and Rangan report a rate of adjustment of $35.5 \%$ per year. They argue that the lower rate found by Fama and French is due to noise in the estimation of TL. ${ }^{2}$

Several studies have examined the rate of adjustment as a function of whether the firm is above or below the target and whether the firm has a financing deficit or surplus. For example, Roberts (2001) finds that the rate of reversion depends on the current position of the firm in relation to its target. He divides the sample into 4 adjustment quartiles and shows that slow-adjusting firms have more long-term debt in their capital structure. He concludes that the rate of adjustment for overlevered firms is faster than for underlevered firms, probably due to higher agency costs. Faulkender et al. (2009) argue that the rate of adjustment is a function of the adjustment cost associated with moving toward the optimal debt ratio. They report varying rates of adjustment based on sunk and incremental costs such that in firm years where adjustment costs are higher, the firm moves more slowly toward its TL. Byoun (2008) finds that most adjustments occur when firms have above-target debt with a financial surplus or when they have below-target debt with a financial deficit.

\footnotetext{
${ }^{2}$ Huang and Ritter (2009) contend that previous studies fail to adjust for biases in the data caused by a "short panel." When they adjust the number of years that a firm is in their data set, they find that the rate of adjustment also changes.
} 


\section{B. Equity Market Timing}

The market timing theory of capital structure as proposed by Baker and Wurgler (2002) states that the capital structure of a firm is the cumulative result of attempts to time the equity market. Baker and Wurgler find that the long-term debt ratio is directly related to the "external finance weighted-average" market-tobook ratio, and they conclude that low-leverage firms raised capital when equity valuations (market-to-book ratios) were high and high-leverage firms raised capital when equity valuations were low. The results of Baker and Wurgler are supported by the survey evidence of Graham and Harvey (2001) and by Huang and Ritter (2009), who, using aggregate measures of market valuation, find evidence of a long-lasting market timing effect on capital structure. Leary and Roberts (2005) also find that shocks to equity valuation can persist for varying lengths of time. Elliott, Koëter-Kant, and Warr (2007), (2008) find that market timing helps to explain the security issuance decision, as firms with overvalued equity tend to favor equity issuances over debt issuances. The market timing theory has, however, drawn criticism from Alti (2006), Flannery and Rangan (2006), and Butler, Cornaggia, Grullon, and Weston (2011), among others, who question the longevity and overall economic significance of market timing.

To date, the literature has not directly addressed the effect of mispricing on the rate of adjustment to the target capital structure. Flannery and Rangan (2006) include market-to-book ratio as a proxy for market timing and find it is significant. However, the rate of adjustment is largely unaffected by its inclusion, and they conclude that the trade-off model still prevails. ${ }^{3}$ In our study we view market timing as altering the cost of adjusting to a target, and the presence of market timing behavior by firms does not preclude the trade-off theory. Instead, we argue that market timing influences the rate at which firms adjust toward their optimal capital structure. We further develop our hypothesis in the next section.

\section{Hypothesis Development}

Rather than view market timing as a stand-alone explanation of capital structure patterns (Baker and Wurgler (2002)), we model market timing as altering adjustment costs within some other capital structure framework, such as the trade-off theory. In this context, market timing is a secondary effect, and hence it would be inappropriate, for example, to run a horse race between the market timing theory and the trade-off theory. By altering the cost of adjustment, market timing may impact the speed at which the firm moves toward its TL.

We conjecture that the speed of adjustment to TL is a function of the firm's equity valuation conditioned on the current leverage position in relation to the target. When equity mispricing and TL effects are aligned (i.e., both effects suggest issuance or repurchase of the same security, either debt or equity), we expect the rate of adjustment to be faster than when the equity mispricing effect is in opposition to the TL effect. For example, when the firm is overlevered (needs to issue

\footnotetext{
${ }^{3}$ In an early study, Jalilvand and Harris (1984) report that firms move back rather quickly to their previous debt level (56\% per year), and that stock valuation seems to impact the speed of adjustment.
} 
equity or reduce debt) and equity is overvalued, we expect the firm to adjust more rapidly than when equity is undervalued. Correspondingly, when a firm is underlevered and equity is undervalued, we would expect the firm to adjust more rapidly by repurchasing equity (or selling debt). Our hypothesis is presented graphically in Table 1.

\section{Data and Method}

\section{A. Sample Selection}

Our initial sample is comprised of all firms on Compustat from 1971 to 2008. We exclude financial firms and utilities (Standard Industrial Classification (SIC) codes 4900-4999 and 6900-6999) due to the regulatory environment they operate in. In addition, we drop non-U.S. firms and firms that have zero book debt. However, as a robustness check we examine the impact of zero-debt firms in Section IV.H. Following Faulkender et al. (2009), we winsorize all ratios at the 1 st and 99th percentiles to minimize the contamination of our sample by miscoded observations and outliers. We augment the data set with data from Center for Research in Security Prices (CRSP) for estimating costs of capital (used in the valuation model) and Institutional Brokers' Estimate System (IBES) for analyst earnings forecasts. As in previous studies, we do not require that firms be continuously listed in the data set, but the residual income model imposes a minimum 4-year survival bias in our sample. Because of the data requirements for the residual income model, we have valuation estimates from 1971 to 2005, resulting in a total of 46,666 firm-year observations.

\section{B. Measuring Equity Valuation}

We measure equity value as the intrinsic value computed using the residual income model. This model has its origins in the accounting literature (see Ohlson (1991), (1995)), and has been applied in a number of finance applications. For example, D'Mello and Shroff (2000) find that undervaluation measured by the residual income model reliably predicts share repurchase activity. Dong, Hirshleifer, Richardson, and Teoh (2006) use the model to explain the method that firms use to pay for acquisitions. Lee, Myers, and Swaminathan (1999) demonstrate that the model has predictive ability for the returns of the Dow 30 stocks, and they support the findings of Frankel and Lee (1998) and Penman and Sougiannis (1998), who also find support for the valuation performance of the residual income model in the cross section of stock returns in domestic and international markets.

In their study of equity mispricing and mergers, Rhodes-Kropf et al. (2005) decompose book-to-market into 2 components: the ratio of (intrinsic) value to market price and the ratio of book value to (intrinsic) value. Rhodes-Kropf et al. interpret the 1st component (value to price (VP)) as a measure of mispricing and the 2nd component (book to value) as a measure of growth opportunities. They show that a VP ratio (using the residual income model to estimate value) better captures mispricing than the book-to-market ratio. Elliott et al. (2007), (2008) use the model to capture capital structure decisions such as the choice between 
debt and equity (equity is favored when it appears overvalued) and the method of funding the financing deficit (again, use equity when it is overvalued).

It is worth discussing further why we do not use market-to-book ratio as a measure of equity mispricing, as market-to-book is frequently employed as a proxy for equity valuation in earlier papers. In many of these capital structure studies however, market-to-book actually performs rather poorly as a proxy for valuation (the notable exception being Baker and Wurgler (2002)). Examples of these studies include Flannery and Rangan (2006), who find little effect of marketto-book on adjustment rates, and Hovakimian (2006), who argues that any relationship between market-to-book and leverage is due to growth opportunities, not market timing.

Market-to-book ratio is a poor proxy for valuation for at least 2 reasons. First, it is frequently used as a proxy for other effects such as growth options and debt overhang problems, and untangling these effects creates its own challenges. Second, the relationship of market-to-book with other variables is not stable across different time periods. For example, the premise that high marketto-book firms underperform low market-to-book firms (La Porta (1996), Frankel and Lee (1998)) appears to be time dependent, as Kothari and Shanken (1997) find that market-to-book ratios have some predictive power over the 1926-1991 period, but that power is substantially reduced during the 1946-1991 subperiod. Lee et al. (1999) find that market-to-book ratios predict only about $0.33 \%$ of the variation in real stock returns, and they conclude that market-to-book is a weak measure of mispricing.

We now turn our discussion back to the residual income model, which is our method of estimating the firm's equity value. The residual income model is estimated by adding the discounted expected earnings in excess of the expected return on book value (this is similar to economic value added (EVA)) to the book value of equity. Equations (2) and (3) are a formal representation of the model:

$$
V_{0}=B_{0}+\sum_{t=1}^{n} \frac{\left(\mathrm{E}_{t}-r \times B_{t-1}\right)}{(1+r)^{t}}+\frac{\mathrm{TV}}{(1+r)^{n} \times r},
$$

where the terminal value (TV) is calculated as

$$
\mathrm{TV}=\frac{\left(\mathrm{E}_{t}-r \times B_{t-1}\right)+\left(\mathrm{E}_{t+1}-r \times B_{t}\right)}{2} .
$$

Here, $V_{0}$ is the value of the firm's equity at time $0, B_{0}$ is the book value at time $0, r$ is the cost of equity, and $\mathrm{E}_{t}$ are the expected future earnings for year $t$ at time 0 . Time 0 is the beginning of the fiscal year, and $n$ equals 2 years. We use 2 versions of the residual income model, one that uses realized earnings (perfect foresight model) and the other that uses analyst's forecasted earnings. ${ }^{4}$ In both models $B_{0}$ (book equity) is Compustat item data60. In the perfect foresight model, $\mathrm{E}_{t}$ (income before extraordinary items) is item data18, while in the analyst forecast model, $\mathrm{E}_{t}$ is the appropriate median IBES analyst forecast made as close

\footnotetext{
${ }^{4}$ D'Mello and Shroff (2000), Lee et al. (1999), Dong et al. (2006), and Elliott et al. (2007) also use analyst forecast data as a robustness check.
} 
to the year end as possible. Both approaches have advantages and disadvantages. The perfect foresight model allows us to use a much larger sample stretching back to 1971, while the analyst forecast model is only viable from 1976 onward (when the IBES earnings data become available). Furthermore, the IBES data cover only a subset of the Compustat universe in a given year, and coverage is thinner in the early years of the data. The perfect foresight model does suffer from the fact that it uses information that is unknown at the time of the capital structure decision, and therefore we are implicitly assuming that managers possess an unbiased expectation of future earnings. As we are not testing a trading rule, the use of forward-looking data should not bias our results, however; the analyst forecast valuation uses only data that are publicly known prior to the capital structure decision, and thus does not suffer from a look-forward bias. Our method does, however, suffer the potential for endogeneity, and we will revisit this issue at the end of this subsection.

The rest of the inputs to the residual income model are estimated using the approach of Lee et al. (1999). We use Fama and French's (1997) 3-factor model (with monthly returns) to calculate the industry cost of equity, $r$, with the shortterm T-bill as a proxy for the risk-free rate of interest. ${ }^{5}$ Lee et al. report that both the short-term T-bill rates and the long-term T-bond rates are useful proxies; however, estimates of the intrinsic value $V_{0}$, based on the short-term T-bill, outperform those based on the long-term T-bond because they have a lower standard deviation and a faster rate of mean reversion. TV is calculated as the average of the last 2 years of the finite series and is restricted to be nonnegative, as a negative TV implies that the firm would continue to invest in negative net present value (NPV) projects in perpetuity.

The estimated intrinsic value of the stock $\mathrm{E}\left(V_{0}\right)$ is compared to the market value of the stock to determine the valuation error. Estimated mispricing is measured as

$$
\mathrm{VP}_{0}=\frac{V_{0}}{P_{0}}
$$

where $\mathrm{VP}_{0}$ is the mispricing at time $0, P_{0}$ is the market price of the stock at time 0 , and $V_{0}$ is the intrinsic value of the stock at time 0 , which is the beginning of the firm's fiscal year. VP should equal 1 in the absence of mispricing. In theory, a VP of less than 1 implies overvaluation, while a VP greater than 1 implies undervaluation. However, because the model relies on a historic measure of the equity risk premium, it is quite possible that fair valuation may not result in VP equal to 1 if the implied risk premium has changed. ${ }^{6}$ Lee et al. (1999) discuss this issue and note that we could just pick a risk premium that results in VP equaling 1 on average. An alternative approach is to use the median VP as the watershed for over- and undervaluation. For our purposes, it is not the degree of misvaluation

\footnotetext{
${ }^{5}$ We also use a fixed risk premium approach as in Lee et al. (1999) and a simple 1-factor model. The results are qualitatively the same. We use the 1-month T-bill rate from Ibbotson and Associates. We obtain this data series from Ken French's Web site (http://mba.tuck.dartmouth.edu/pages/faculty/ ken.french/Data_Library/f-f_factors.html).

${ }^{6}$ The equity premium is the 60 -month rolling average of the difference between the return on the Standard \& Poor's (S\&P) 500 Index and the long-term T-bond.
} 
that matters, only whether the stock is over- or undervalued and whether one stock is misvalued relative to another. Nevertheless, considering that the analyst forecast valuations are more heavily distributed during the 1990s, a time during which market valuations were relatively high, we use the median VP as the boundary for over- and undervaluation rather than the theoretical cutoff of $1 .^{7}$

Finally, a potential source of endogeneity could exist in our earnings-based method, but we believe that this endogeneity will actually bias against our finding a significant result. ${ }^{8}$ This potential endogeneity occurs because in our model, firm value and leverage could be mechanically related. Consider, for example, a firm with relatively high future earnings that we have classified as being overlevered. High earnings will lead to a relatively high valuation estimate from the residual income model and, as a result, the firm is more likely to be categorized as undervalued. The high earnings will also lead to higher retained earnings and a mechanical decline in future leverage. Therefore, if, at time 0 , the firm is undervalued and overlevered, we would predict that it would adjust more slowly to its target (see Table 1 for the predicted speed of adjustment). However, because of the mechanical reduction in leverage, the firm will actually adjust much more quickly (counter to our prediction). Similarly, if this firm were categorized as underlevered, we would predict that the firm would adjust back to its target more rapidly (since its equity is undervalued, the firm would be more likely to repurchase stock). Yet, due to high retained earnings, the firm would tend to become ever more underlevered, and the rate of adjustment would appear slower. Both situations are counter to our hypotheses and indeed to our empirical findings.

\section{Implementation of the Partial Adjustment Model}

We use a 2-stage approach to estimate speeds of adjustment. In the 1st stage, we estimate TL using 2 different empirical approaches, namely those of Fama and French (2002) and Blundell and Bond (1998). In the 2nd stage, we use these $\mathrm{TL}$ ratios in ordinary least squares (OLS) regressions bifurcated by the valuation measure to estimate differential speeds of adjustment (as in equation (1)). We are largely agnostic about the 1st-stage method for estimating the TL, and our use of 2 different empirical approaches is purely for robustness reasons.

We base our choice of variables for the 1st-stage TL regressions on Hovakimian et al. (2001) and Hovakimian and Li (2011) and include firm size, asset tangibility, market-to-book ratio, research and development (R\&D) expense, and median industry leverage. Firm size is the log of Sales (Compustat data12) adjusted for inflation. R\&D expense (data46) is scaled by sales. We also include a dummy variable for firms that report nonzero R\&D. Tangibility is net property, plant, and equipment (data8) scaled by total assets. Market-to-book is computed as book debt plus the market value of equity over book assets ([data9 + data34 + data10 + data199 $\times$ data25]/data6). We compute both BDRs and MDRs. While anecdotal evidence suggests that managers pay closer attention to book

\footnotetext{
${ }^{7}$ Our results are qualitatively unaffected if we use $\mathrm{VP}=1$ rather than $\mathrm{VP}=$ median $\mathrm{VP}$ as the boundary for over- and undervaluation.

${ }^{8}$ We thank the referee for making this observation.
} 
ratios, market ratios have a more theoretical basis when computing optimal costs of capital. The BDR is computed as (data9 + data34)/data6 and the MDR as (data9 + data34) $/($ data $9+$ data34 + (data199 $\times$ data25 $))$. To reduce concerns of endogeneity, we estimate adjustment speeds over the year following the estimation of the VP measure. Similarly, all other variables used in the estimations are lagged 1 period to avoid reverse causality.

Table 2 presents the summary statistics of these variables and the valuation measures. The average BDR for all firms is about 25\%, compared to an MDR of approximately $31 \% .^{9}$ The average sales (in 1983 dollars) are $\$ 1.391$ billion. The mean market-to-book ratio is 1.28 . The mean and median VP ratios for the perfect foresight model are 0.975 and 0.779 , respectively. The 1st and 99th percentiles for the VP ratio are 0.112 and 2.731, respectively. Using analyst forecast earnings to estimate the VP ratio (analyst VP) shifts the distribution to the left. The mean and median analyst VPs are 0.789 and 0.640 , respectively, while the 1st and 99th percentiles are 0.059 and 2.288 , respectively.

\section{TABLE 2}

\section{Sample Summary Statistics}

All the variables are computed using data from Compustat. BDR is the book debt ratio: (data9 + data34)/data6. MDR is the market debt ratio: $($ data9 + data34)/(data9 + data34 + data199 $\times$ data25). Asset Tangibility is the ratio of fixed assets (property, plant, and equipment) to total assets (data8/data6). Market-to-book ratio: (data9 + data34 + data10 + data199 $\times$ data25)/data6. $R \& D$ to sales is R\&D expense divided by sales: data46/data12. R\&D dummy is a dummy variable that takes the value 1 when the firm reports R\&D expense, and 0 otherwise. VP is the value-to-price ratio measured as the valuation calculated from the residual income valuation model divided by the stock price (see Section III.B for full details). Analyst VP is the VP ratio measured based on analyst earnings forecasts in the valuation model.

\begin{tabular}{|c|c|c|c|c|c|}
\hline Variable & Mean & Median & $\begin{array}{l}\text { Standard } \\
\text { Deviation } \\
\end{array}$ & $\begin{array}{c}1 \text { st } \\
\text { Percentile } \\
\end{array}$ & $\begin{array}{c}\text { 99th } \\
\text { Percentile } \\
\end{array}$ \\
\hline BDR & 0.254 & 0.238 & 0.169 & 0.002 & 0.711 \\
\hline MDR & 0.306 & 0.260 & 0.238 & 0.001 & 0.883 \\
\hline Sales ( $\$$ millions) & $1,391.046$ & 104.954 & $7,031.561$ & 0.206 & $24,185.240$ \\
\hline Asset Tangibility & 0.361 & 0.314 & 0.233 & 0.008 & 0.922 \\
\hline Market-to-book & 1.283 & 0.911 & 1.413 & 0.295 & 6.361 \\
\hline R\&D to sales & 0.056 & 0.000 & 0.370 & 0.000 & 0.991 \\
\hline R\&D dummy & 0.450 & 0.000 & 0.498 & 0.000 & 1.000 \\
\hline Median industry BDR & 0.213 & 0.219 & 0.085 & 0.018 & 0.409 \\
\hline Median industry MDR & 0.298 & 0.268 & 0.195 & 0.012 & 0.957 \\
\hline $\operatorname{VP}(n=46,666)$ & 0.975 & 0.779 & 0.708 & 0.112 & 2.731 \\
\hline Analyst VP $(n=22,638)$ & 0.789 & 0.640 & 0.580 & 0.059 & 2.288 \\
\hline
\end{tabular}

As discussed earlier, we use 2 alternative empirical approaches to estimate TL. The 1st approach, that of Fama and French (2002), uses the Fama and MacBeth (1973) cross-sectional leverage regressions estimated annually. We estimate the TL for both the BDR and the MDR. The predicted values from these regressions are used as the variable TL in the estimation of equation (1) to obtain the baseline speed of adjustment as the coefficient estimate on $\left[\mathrm{TL}_{t+1}-\mathrm{DR}_{t}\right]$, or DISTANCE.

Table 3 presents the average annual slope coefficient estimates from the Fama and French (2002) approach. We report time-series standard errors, which are the standard deviation of the $n$ slope estimates divided by $\sqrt{n}$. These

\footnotetext{
${ }^{9}$ Flannery and Rangan (2006) also report MDRs higher than BDRs using this approach to compute market debt.
} 
regressions indicate that firms with more intangible assets and greater amounts of R\&D tend to have lower levels of debt. Larger firms tend to have higher MDRs. These findings are broadly consistent with those of other researchers. ${ }^{10}$

\section{TABLE 3}

\section{Average Coefficients from Annual Leverage Regressions}

\begin{tabular}{|c|c|c|}
\hline Variable & $\mathrm{BDR}_{t+1}$ & $\mathrm{MDR}_{t+1}$ \\
\hline Intercept & $\begin{array}{l}0.1579^{\star \star \star} \\
(31.29)\end{array}$ & $\begin{array}{l}0.3052^{\star \star \star} \\
(25.49)\end{array}$ \\
\hline In(Sales) & $\begin{array}{l}-0.0005 \\
(-0.43)\end{array}$ & $\begin{array}{l}0.0013^{\text {** }} \\
(2.10)\end{array}$ \\
\hline Fixed Assets/Total Assets & $\begin{array}{l}0.1143^{\text {*** }} \\
(15.96)\end{array}$ & $\begin{array}{l}0.0607^{\star \star \star} \\
(5.53)\end{array}$ \\
\hline Market-to-book & 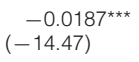 & $\begin{array}{l}-0.0791^{\text {** }} \\
(-9.15)\end{array}$ \\
\hline R\&D dummy & $\begin{array}{l}-0.0283^{\text {*** }} \\
(-10.11)\end{array}$ & $\begin{array}{l}-0.0421^{\text {***}} \\
(-12.34)\end{array}$ \\
\hline R\&D to sales & $\begin{array}{l}0.0309 \\
(0.83)\end{array}$ & $\begin{array}{l}-0.0908^{* *} \\
(-2.22)\end{array}$ \\
\hline Industry median debt ratio & $\begin{array}{l}0.4139^{\star \star \star} \\
(15.61)\end{array}$ & $\begin{array}{l}0.2988^{\star \star \star} \\
(20.31)\end{array}$ \\
\hline $\begin{array}{l}N \\
\text { Average } R^{2}\end{array}$ & $\begin{array}{r}46,666 \\
0.138\end{array}$ & $\begin{array}{r}46,666 \\
0.217\end{array}$ \\
\hline
\end{tabular}

The 2nd approach that we use to estimate TL is based on Blundell and Bond (1998), which employs system generalized method of moments (GMM). ${ }^{11}$ In this approach, the basic adjustment model is specified as

$$
\mathrm{DR}_{i, t+1}-\mathrm{DR}_{i, t}=\lambda\left(\beta X_{i, t}+F_{i}-\mathrm{DR}_{i, t}\right)+e_{i, t+1},
$$

where DR is the debt ratio, $X$ contains the determinants of TL discussed previously, $F$ contains unobserved firm attributes, and $e_{i, t+1}$ contains year fixed effects. Equation (5) is identical to equation (1) except that $\beta X+F$ are used as the instruments for the unknown TL. Equation (5) can be rearranged to isolate the future debt ratio, and to provide an explicit estimate of the speed of adjustment, $\lambda$ :

$$
\mathrm{DR}_{i, t+1}=(\lambda \beta) X_{i, t}+(1-\lambda) \mathrm{DR}_{i, t}+\lambda F_{i}+e_{i, t+1} .
$$

The baseline speed of adjustment, $\lambda$, can simply be obtained by subtracting the coefficient estimate on the lagged dependent variable from 1.

\footnotetext{
${ }^{10}$ The notable exception is Korteweg (2010), who uses a different method for estimating the TL.

${ }^{11}$ The Blundell and Bond (1998) method is used in the literature as a means of tackling dynamic panel bias (see Flannery and Rangan (2006)). In unpublished work, Flannery and Hankins (2007) evaluate several dynamic panel estimators and conclude that the Blundell and Bond method is least prone to dynamic panel bias. Lemmon et al. (2008) and Faulkender et al. (2009) and others employ the Blundell and Bond approach in their studies of adjustment speeds.
} 
Using the actual $\mathrm{DR}_{i, t}, \mathrm{DR}_{i, t+1}$, and the estimated speed of adjustment $(\lambda)$, we can extract the predicted target leverage $\mathrm{TL}_{i, t+1}$ as the predicted value of equation (7):

$$
\beta X_{i, t}+F_{i}=\left(\frac{1}{\lambda}\right)\left(\mathrm{DR}_{i, t+1}-(1-\lambda) \mathrm{DR}_{i, t}\right)+e_{i, t+1}
$$

We note that while some authors use the speed of adjustment estimates that are generated directly by the Blundell and Bond's (1998) estimation of equation (6) (i.e., the $\lambda$ ), we extract the targets from equation (7) and use them in the 2 nd stage of our analysis by estimating equation (1) to obtain the baseline speed of adjustment as the coefficient estimate on $\left[\mathrm{TL}_{t+1}-\mathrm{DR}_{t}\right]$, or DISTANCE. Our 2-stage approach allows us to compare the results generated by the Fama and French (2002) targets directly with those generated by the Blundell and Bond targets. Our approach also allows us to bifurcate the data based on the firm's leverage position relative to the target. While it is possible to estimate the Blundell and Bond targets first, then bifurcate the data and rerun the Blundell and Bond model on the bifurcated data to estimate a speed of adjustment, such an approach would gain little econometrically over using OLS in the 2nd stage and would make direct comparisons of adjustment speeds between Blundell and Bond targets and Fama and French targets more difficult. As a point of comparison however, we do estimate the baseline adjustment speeds directly from equation (6) for the initial baseline regressions before we bifurcate the data. We report these results in Section IV.A when we discuss the baseline adjustment speeds.

Several authors have argued that weaknesses exist in the partial adjustment framework. Chang and Dasgupta (2009) argue that partial adjustment models in general may fail to reject the null hypothesis of no speed of adjustment. Hovakimian and Li (2011) extend the work of Chang and Dasgupta and outline precautions that users of partial adjustment models should take to avoid spurious results when analyzing historical data with fixed effects. These include using only historical fixed effects and, in the case of the single-step approach, using the GMM method of Blundell and Bond (1998). Our implementations of the Fama and French (2002) and the Blundell and Bond approaches employ their recommendations. Hovakimian and $\mathrm{Li}$ also address the issue of mechanical mean reversion, which we will fully address in Section IV.A.

Graphically, we present the results of the TL estimation in Figure 1. We find that both the Fama and French (2002) approach as well the Blundell and Bond (1998) approach produce some target estimates that are outside the 0 to 1 interval. The Blundell and Bond targets tend to be more widely distributed than the Fama and French targets. The following sections employ these targets in the 2-stage analysis.

\section{Results}

\section{A. Estimation of Adjustment Speeds}

The 1st column of Table 4 presents the baseline speeds of adjustment ( $\lambda$ in equation (1)) obtained for the overall sample using targets estimated by the Fama 
and French (2002) and the Blundell and Bond (1998) approaches, with both book and market definitions of leverage. Equation (1) is estimated with year dummy variables, firm fixed effects, and standard errors corrected for heteroskedasticity and firm-level clustering.

Since $\mathrm{TL}_{t+1}-\mathrm{DR}_{t}$, or DISTANCE, is calculated as the predicted target debt ratio minus the observed debt ratio, overlevered firms have a negative DISTANCE

FIGURE 1

\section{Target Debt Ratios}

Graphs A-D of Figure 1 present target book and market debt ratios estimated using the Blundell and Bond (1998) and Fama and French (2002) methods. The horizontal axis represents the target debt ratio while the vertical axis represents the number of observations in each discrete debt ratio bin. The target debt ratio bins are $2 \%$ wide. The dashed vertical lines mark the $0 \%$ and $100 \%$ debt ratio levels.

Graph A. Blundell and Bond Target Book Debt Ratio

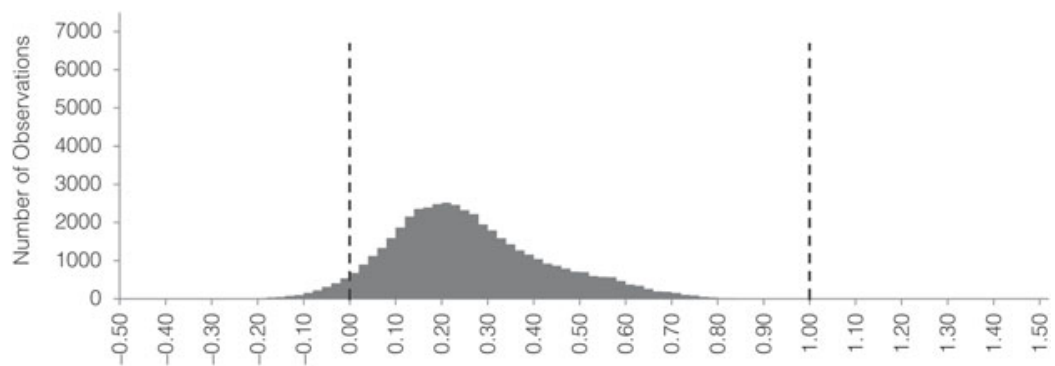

Target Debt Ratio

Graph B. Blundell and Bond Target Market Debt Ratio

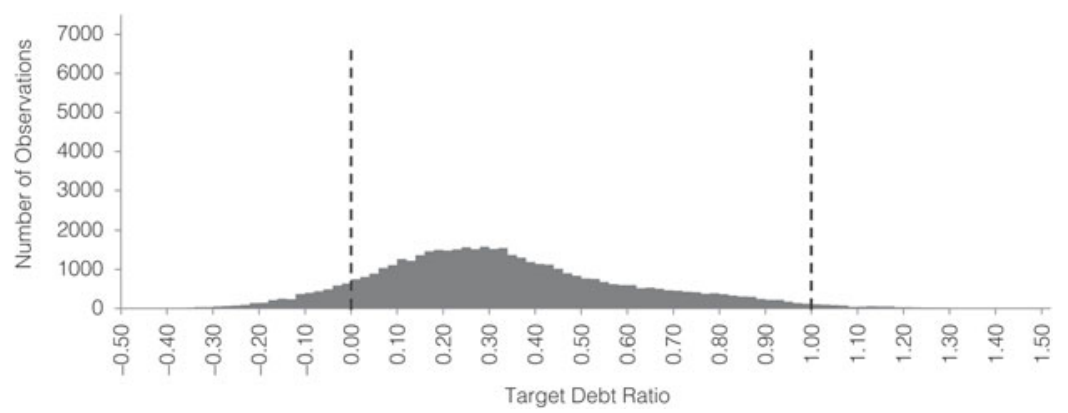

Graph C. Fama and French Target Book Debt Ratio

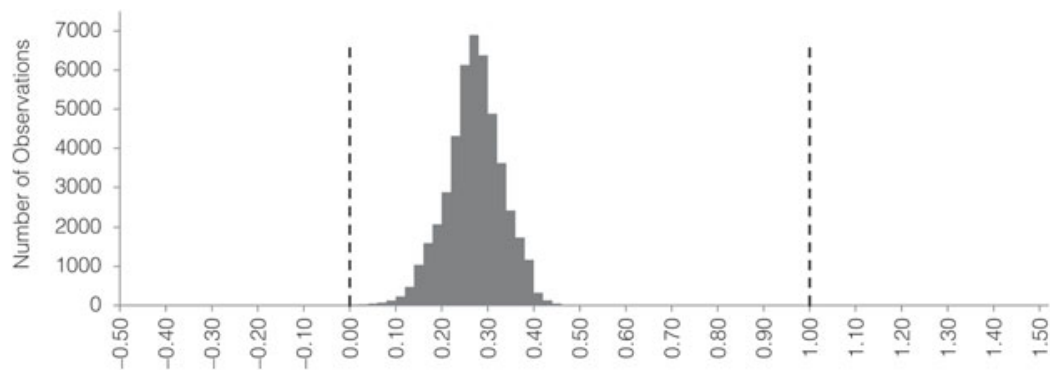

Target Debt Ratio 
FIGURE 1 (continued)

Target Debt Ratios

Graph D. Fama and French Target Market Debt Ratio

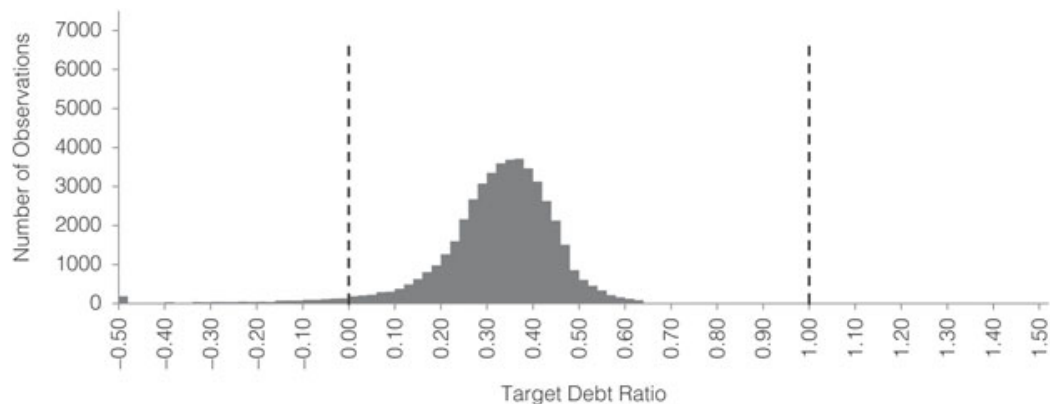

TABLE 4

Baseline Speeds of Adjustment and Potential for Mechanical Mean Reversion

Table 4 presents the baseline speed of adjustment estimates $(\lambda)$ obtained from the regression of the equation

$$
\mathrm{DR}_{t+1}-\mathrm{DR}_{t}=\lambda\left[\mathrm{TL}_{t+1}-\mathrm{DR}_{t}\right]+e_{t+1},
$$

where $\mathrm{DR}_{t+1}$ is the debt-to-assets ratio in period $t+1$ and $\mathrm{TL}_{t+1}$ is the target debt ratio in period $t+1$ obtained using the Fama and French (2002) and Blundell and Bond (1998) approaches for estimating the target book debt ratio (BDR) and target market debt ratio (MDR). Please see Section III.C for details. The distance $\left[\mathrm{TL}_{t+1}-\mathrm{DR}_{t}\right]$ is the total amount that the debt ratio must change to bring the firm back to its target debt ratio. Panel A presents the results with ex post earnings valueto-price (VP) ratio, whereas Panel B presents the results with analyst forecast earnings VP ratio. The 1st column presents the full sample results. The 2nd column presents the results for the subset, which includes firms with debt ratios between 0.1 and 0.9 . The $t$-statistics (in parentheses) are corrected for heteroskedasticity and firm-level clustering. Regressions include unreported year dummy variables and firm fixed effects, and ${ }^{* * *}$, ${ }^{* *}$, and * indicate significance at the $1 \%, 5 \%$, and $10 \%$ levels, respectively.

Panel A. Ex Post Earnings VP Ratio

Fama and French MDR

Fama and French BDR

Blundell and Bond MDR

Blundell and Bond BDR

Panel B. Analyst Forecast Earnings VP Ratio

Fama and French MDR

Fama and French BDR

Blundell and Bond MDR

Blundell and Bond BDR
Full Sample

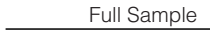

$$
\begin{aligned}
& 0.3536^{\star * *} \\
& (51.46) \\
& 0.3325^{\star * *} \\
& (49.92) \\
& 0.2925^{\star \star *} \\
& (48.55) \\
& 0.2770^{\star * *} \\
& (44.17)
\end{aligned}
$$

$0.3705^{\star \star *}$

$0.3426^{* * *}$

(33.46)

$0.2816^{* * *}$

(31.75)

$0.2759^{\text {** }}$ (30.31)

$$
\begin{aligned}
& n=46,666 \\
& n=46,666 \\
& n=46,666 \\
& n=46,666
\end{aligned}
$$

$$
n=22,570
$$$$
n=22,570
$$$$
\text { ก }
$$$$
n=22,570
$$$$
n=22,570
$$

$0.1<\mathrm{DR}<0.9$ 
and French (2002) found adjustment speeds of 7\%-18\%, and Flannery and Rangan (2006) found speeds of around 35\%. As noted earlier, we can also estimate the Blundell and Bond (1998) adjustment speeds in the 1st stage of the model from equation (6). For comparison purposes, these are $18.50 \%$ for market debt and $20.06 \%$ for book debt.

Shyam-Sunder and Myers (1999), among others (Chen and Zhao (2007), Chang and Dasgupta (2009), and Hovakimian and Li (2011)), argue that mechanical mean reversion can lead to an upward bias in the speeds of adjustment, preventing the model from rejecting the null hypothesis that the speed of adjustment is 0 . These authors suggest that leverage observations greater than $90 \%$ and less than $10 \%$ be removed to mitigate this issue, since a leverage change for these firms is more likely to be to the mean. In the 2 nd column of Table 4 we drop these extreme observations and rerun the tests. Surprisingly, we observe virtually no change in the estimated speeds of adjustment. In fact, in all but one case, the speeds without these high- and low-leverage firms are actually higher than for the full sample. We are therefore reluctant to accept that in our sample the highand low-leverage firms are causing an upward bias in the estimates. Furthermore, dropping these firms comes at a cost: 9,878 and 11,640 observations are lost because of book leverage and market leverage less than $10 \%$, respectively. The number of high-leverage $(>90 \%)$ firms dropped is much smaller ( 0 and 330 for book and market leverage, respectively). Recall that prior to using this filter we have already culled the sample for firms with debt ratios equal to 0 , thus we are not just removing zero-debt firms. Because of the significant number of observations lost and the lack of evidence of a significant bias, we pursue our main tests using the full sample.

So far we have estimated a uniform speed of adjustment for the overall sample. However, the main contribution of this paper is to allow for heterogeneity in the speed of adjustment toward TL among over- and underlevered and over- and undervalued firms. That is, we conjecture that the speed of adjustment may vary across different groupings of firms based on their current status relative to their target and the misvaluation of their equity. Therefore, we now relax the restriction of a sample-wide constant speed of adjustment.

Our basic empirical approach for testing adjustment speeds throughout the rest of the paper is to divide the sample into subsamples based on the variables of interest (such as whether the firm is over- or underlevered and over- or undervalued). The adjustment speed regression specified in equation (1) is then run separately on each subsample, incorporating year dummy variables, firm fixed effects, and robust errors clustered at the firm level. ${ }^{12}$

This method implicitly assumes that firms can move from one subsample to another through time (e.g., if an overlevered firm later becomes underlevered). This mixing of the observations is desirable, as it helps to ensure that our tests

\footnotetext{
${ }^{12}$ This method is widely used in related literature. For example, Fama and French (2002) and Flannery and Rangan (2006) run separate regressions on subsamples. Similarly, Faulkender et al. (2009) estimate adjustment speeds for each subset of their data. Alternatively, rather than estimating separate regressions, we could estimate equation (1) for the overall sample by interacting dummy variables indicating whether the firm falls into a particular group in a particular year with the adjustment speeds. Our conclusions are robust to either estimation method.
} 
are not just capturing unobserved characteristics that are specific to a particular subsample of firms. A quick look at the data reveals that for the Fama and French (2002) MDR observations, there are 13,809 quadrant changes out of a total of 46,666 firm years. Thus, on average, $30 \%$ of the firms change quadrant in a given year.

\section{B. Examining the Effect of Valuation on Adjustment Speeds}

To examine the effect of valuation on adjustment speeds, we divide the data into 4 subsamples based upon valuation and leverage (i.e., see Table 1 for expected adjustment speed differences). Separate adjustment regressions are then estimated for data in each quadrant subsample using year dummy variables and firm clustered standard errors. Table 5 gives the coefficients on the DISTANCE variable $(\lambda)$ obtained from estimating equation (1) for each quadrant (in this table we use the perfect foresight model to determine mispricing).

\section{TABLE 5}

\section{Speed of Adjustment Regressions Using Ex Post Earnings Value-to-Price Ratio}

Table 5 presents the speed of adjustment estimates $(\lambda)$ obtained from separate regressions of the following equation for subsamples of firm years based on whether the firm is over- or underlevered and over- or undervalued:

(1)

$$
\mathrm{DR}_{t+1}-\mathrm{DR}_{t}=\lambda\left[\mathrm{TL}_{t+1}-\mathrm{DR}_{t}\right]+e_{t+1}
$$

where $\mathrm{DR}_{t+1}$ is the debt-to-assets ratio in period $t+1$ and $\mathrm{TL}_{t+1}$ is the target debt ratio in period $t+1$ obtained using the Fama and French (2002) and Blundell and Bond (1998) approaches for estimating the target book debt ratio (BDR) and target market debt ratio (MDR). Please see Section III.C for details. The distance $\left[\mathrm{TL}_{t+1}-\mathrm{DR} \mathrm{R}_{t}\right]$ is the total amount that the debt ratio must change to bring the firm back to its target debt ratio. The value-to-price (VP) ratio is computed using the perfect foresight residual income model. Panels $A$ and $B$ report results from the Fama and French targets using the MDR and $\mathrm{BDR}$, respectively. Panels $\mathrm{C}$ and $\mathrm{D}$ report results from the Blundell and Bond targets using the MDR and BDR, respectively. The 1st and 2nd columns present the results for firm years with overvalued and undervalued equity, respectively. The 3rd column presents the $t$-statistic ( $p$-value) for the difference between the coefficients in the first 2 columns. The $t$-statistics (in parentheses) for the adjustment speeds are corrected for heteroskedasticity and firm-level clustering. Regressions include unreported year dummy variables and firm fixed effects, and ${ }^{* * *}$, ${ }^{* *}$, and * indicate significance at the $1 \%, 5 \%$, and $10 \%$ levels, respectively.

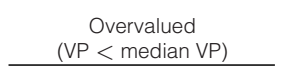

Panel A. MDRs Using Fama and French Targets

Overlevered (DISTANCE < 0) $0.5353^{\star \star \star}$

$$
\text { (20.01) }
$$

Underlevered (DISTANCE >0)

$0.2436^{\star \star \star}$ (14.01)

Panel B. BDRs Using Fama and French Targets

Overlevered (DISTANCE <0)

Underlevered (DISTANCE >0)

$$
\begin{aligned}
& 0.4531^{\text {*ᄎ }} \\
& \text { (23.89) } \\
& 0.3801^{\text {** }} \\
& \text { (20.84) }
\end{aligned}
$$

Panel C. MDRs Using Blundell and Bond Targets

Overlevered (DISTANCE <0)

$$
\begin{aligned}
& 0.3185^{\text {} \star \star} \\
& (19.24) \\
& 0.1668^{\star \star \star} \\
& (12.80)
\end{aligned}
$$

Panel D. BDRs Using Blundell and Bond Targets

Overlevered (DISTANCE < 0)

Underlevered (DISTANCE > 0)

$$
\begin{array}{ll}
n=8,551 & 0.3384^{\star \star \star} \\
n=14,782 & (21.49) \\
0.4042^{\star \star *} & (20.69)
\end{array}
$$

Undervalued

$(\mathrm{VP}>$ median VP)

Difference

$t$-Stat ( $p$-value)

$$
\begin{array}{cccc} 
& & & \\
n=10,650 & 0.2992^{* * *} & & 6.11^{* * *} \\
& (17.93) & n=11,151 & (<0.001) \\
& 0.4140^{* * *} & & -1.40 \\
n=12,683 & (24.76) & n=12,182 & (0.172)
\end{array}
$$

$$
\begin{array}{lccc}
n=8,816 & 0.2960^{\star \star \star} & & 1.15 \\
& (25.65) & n=13,811 & (0.250) \\
n=14,517 & 0.2672^{\star \star \star} & & -4.79^{\star \star \star} \\
& (16.10) & n=9,522 & (<0.001)
\end{array}
$$


We first discuss Panels A and B of Table 5, which report results that use the Fama and French (2002) targets for the MDR and BDR, respectively. The 1st row of Panel A compares the rate of adjustment between firms with over- and undervaluation when firms are above their target debt ratio. The 2 nd row presents the same comparison for underlevered firms. The coefficients on DISTANCE are significant at the $1 \%$ level in all cases and lie within the $24 \%-54 \%$ range. These adjustment speeds seem broadly plausible, given prior research.

For firms that are above their TL, we expect overvalued firms to adjust back toward their targets more rapidly than undervalued firms. ${ }^{13}$ Using the Fama and French (2002) TL and MDRs, we find that the overvalued firms have an adjustment speed of about $54 \%$, while the undervalued firms have a lower adjustment speed of $34 \%$. The difference between these 2 estimates is highly significant with a $t$-statistic of 6.75 . The difference in the adjustment speeds is not only statistically significant, but also economically significant. Overvalued firms adjust to their target in about 1.9 years, while undervalued firms take almost 3 years. ${ }^{14}$

Likewise, for underlevered firms, we expect those firms whose share price is above fundamental value to adjust more slowly than those firms whose share price is below fundamental value. Again, focusing on the market debt results using the Fama and French (2002) TL, we find that underlevered, overvalued firms adjust more slowly, at a rate of $24.4 \%$ per year, while underlevered, undervalued firms adjust more rapidly, at $40 \%$ per year. This difference is highly significant, with a $t$-statistic of -6.09 .

Panel B of Table 5 reruns these tests using the BDR (and the Fama and French (2002) targets) and finds a significantly faster rate of adjustment for overvalued firms that are above their TL (at the 1\% level). For undervalued firms that are below their TL, the sign is correct, but the difference is insignificant $(t=1.40)$ using a 2-tailed test.

Panels $\mathrm{C}$ and D of Table 5 present the results using the Blundell and Bond (1998) TL and the MDR and BDR, respectively. All results are qualitatively similar to those using the Fama and French (2002) targets. However, for overlevered (as measured by the market debt) firms in Panel $\mathrm{C}$, the difference in the rate of adjustment between over- and undervalued firms is not significantly different (although the sign is correct). Table 5, overall, provides strong evidence that equity mispricing is an important factor in the rate at which firms adjust to a capital structure target and represents the primary result of our paper. A firm's rate of adjustment toward its target is heavily influenced by the degree to which it is favorable to issue or repurchase equity securities. In other words, when market conditions are favorable, the firm adjusts much more rapidly. ${ }^{15}$

\footnotetext{
${ }^{13}$ We do not directly compare the quadrants of Table 1 vertically (i.e., holding valuation constant and comparing by leverage), as our study focuses on the effect of valuation on the financing decision given a leverage position. In addition, Welch (2004) notes that the use of MDRs will mechanically result in more rapid adjustment rates for overlevered firms than for underlevered firms.

${ }^{14}$ The calculations are $1 / 0.54$ and $1 / 0.34$ for overvalued and undervalued firms, respectively.

${ }^{15}$ In unreported tests, we bifurcate the data based on whether the firm is close to or further away from the target and rerun the Table 5 tests. We find that the valuation effect strongly persists for firms that are greater than 10 percentage points from the target but is much weaker for firms that are close to the target. We suspect that this is because the target is estimated with error, and there is a greater
} 


\section{Subperiod Robustness}

To test whether our results are being driven by specific subperiods, we divide the main perfect foresight sample into 3 subsamples (1971-1982, 1983-1994, and 1995-2005) and we rerun the Table 5 tests on each subsample. For each set of targets (Fama and French (2002), Blundell and Bond (1998), MDR, and BDR), we run a total of 6 regressions: 2 for each subperiod ( 1 for the overlevered firms and 1 for the underlevered firms). We find that when we use the Fama and French MDR targets, our results are robust to every time period. In addition, the Fama and French BDR targets are robust in 4 of 6 regressions. Consistent with our earlier results, we see weaker performance of the Blundell and Bond MDR targets, which perform the worst and are only significant in 2 of the 6 models. Overall, we conclude that our results are broadly robust to subperiods. We omit the presentation of these results to conserve space.

\section{Valuation Measure Robustness}

In Table 6 we examine the robustness of the results by using the analyst forecast valuation model instead of the perfect foresight model. To ensure consistency between the valuation estimates and the TL estimates, we reestimate the target debt ratios for the analyst sample. Again we find evidence that firms appear to adjust more rapidly to their TL when it is more favorable from an equity valuation standpoint. Five of the 8 differences are significant and have the same signs as in Table 5. One of the remaining 3 differences (Panel C of Table 6, overlevered) has the wrong sign but is also insignificant. Overall, the Fama and French (2002) targets (Panels A and B of Table 6) support the primary findings, while the Blundell and Bond (1998) targets (Panels C and D of Table 6) are weaker.

We do not think that the difference in results between Tables 5 and 6 is due to sample size or time period covered. Although the main data set (Table 5) contains valuation estimates from 1971 to 2005 , and the analyst data set contains valuation estimates from 1976 to 2005, it seems unlikely that a 5-year difference could explain the difference in the results. Furthermore, even though the sample size is smaller, 22,570 observations is still large in absolute terms. We conjecture that the difference could be either due to the efficacy of the analyst model or to the analyst model firms being somehow different from the perfect foresight firms. To examine these possibilities in more detail, we rerun the Table 5 perfect foresight model tests on the subsample of analyst firms. We report these results in Table 7 . The sample size becomes smaller (17,805 firms compared to 22,570 in Table 6) because some firms with analyst coverage are not in the perfect foresight sample. This could occur if a firm has analyst forecasts for the next 2 years but merges or is delisted before the time periods of the forecasts are realized. Overall, the adjustment speeds and significance levels are similar to those reported

chance that firms that are close to their target are being misclassified as being over- or underlevered. Although not mutually exclusive, an additional explanation is that those firms that are further from their target are likely to adjust more quickly as the benefits of adjustment likely exceed the transaction costs. 
TABLE 6

\section{Speed of Adjustment Regressions Using the Analyst Earnings Forecast Value-to-Price Ratio}

Table 6 presents the speed of adjustment estimates $(\lambda)$ obtained from separate regressions of the following equation for subsamples of firm years based on whether the firm is over- or underlevered and over- or undervalued:

$$
\mathrm{DR}_{t+1}-\mathrm{DR}_{t}=\lambda\left[\mathrm{TL}_{t+1}-\mathrm{DR}_{t}\right]+e_{t+1}
$$

where $\mathrm{DR}_{t+1}$ is the debt-to-assets ratio in period $t+1$ and $\mathrm{TL}_{t+1}$ is the target debt ratio in period $t+1$ obtained using the Fama and French (2002) and Blundell and Bond (1998) approaches for estimating the target book debt ratio (BDR) and target market debt ratio (MDR). Please see Section III.C for details. The distance $\left[\mathrm{TL}_{t+1}-\mathrm{DR}_{t}\right]$ is the total amount that the debt ratio must change to bring the firm back to its target debt ratio. The value-to-price (VP) ratio is computed using the analyst earnings forecast residual income model. Panels A and B report results from the Fama and French targets using the MDR and BDR, respectively. Panels $C$ and $D$ report results from the Blundell and Bond targets using the MDR and BDR, respectively. The 1st and 2nd columns present the results for firm years with overvalued and undervalued equity, respectively. The 3rd column presents the $t$-statistic ( $p$-value) for the difference between the coefficients in the first 2 columns. The $t$-statistics (in parentheses) for the adjustment speeds are corrected for heteroskedasticity and firmlevel clustering. Regressions include unreported year dummy variables and firm fixed effects, and ${ }^{* *},{ }^{* *}$, and ${ }^{*}$ indicate significance at the $1 \%, 5 \%$, and $10 \%$ levels, respectively.

\section{Overvalued
$(\mathrm{VP}<$ median VP)}

Panel A. MDRs Using Fama and French Targets

$\begin{array}{lc}\text { Overlevered (DISTANCE < 0) } & 0.5348^{\star \star \star} \\ \text { Underlevered (DISTANCE >0) } & 0.2490^{\star \star \star} \\ & (10.53)\end{array}$

Panel B. BDRs Using Fama and French Targets

\begin{tabular}{lc}
\hline Overlevered (DISTANCE < 0) & $0.4348^{\star \star \star}$ \\
Underlevered (DISTANCE > 0) & $0.3468^{\star \star \star}$
\end{tabular}

(13.41)

Panel C. MDRs Using Blundell and Bond Targets

$\begin{array}{lc}\text { Overlevered (DISTANCE < 0) } & 0.3126^{\star \star \star} \\ \text { Underlevered (DISTANCE > 0) } & 0.2085^{\star \star \star}\end{array}$

Panel D. BDRs Using Blundell and Bond Targets

$\begin{array}{ll}0.2956^{\star \star \star} & \\ \text { Overlevered (DISTANCE < })\end{array}$

Underlevered (DISTANCE $>0$ ) $\quad 0.3172^{\star \star \star}$

(14.19)

$$
\begin{array}{lccc}
n=4,606 & 0.4482^{\star \star \star} & & 1.82^{\star} \\
& (16.59) & n=6,105 & (0.070) \\
n=6,679 & (11.27) & n=5,180 & (<0.001)
\end{array}
$$$$
\text { (1) }
$$

$$
\begin{array}{lccc} 
& 0.3658^{\star \star \star} & & 1.80^{\star} \\
n=4,963 & (14.72) & n=5,750 & (0.072) \\
& 0.4154^{\star \star \star} & & -1.86^{\star} \\
n=6,322 & (15.88) & n=5,535 & (0.063)
\end{array}
$$

$\begin{array}{lccc}n=4,257 & 0.3370^{\star \star \star} & & -0.81 \\ & (18.51) & n=6,650 & (0.415) \\ n=7,028 & 0.3356^{\star \star \star} & & -3.79^{\star \star \star} \\ & (12.45) & n=4,635 & (<0.001)\end{array}$

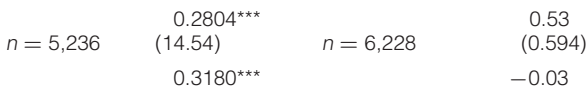

$n=6,049 \quad(13.40)$

in Table 6, suggesting that the difference lies in the characteristics of the firms with analyst coverage compared to those firms in the full sample. It may be that the analyst coverage firms are less likely to be systematically misvalued because, by definition, they have analyst coverage. They also are larger. The average full sample firm size is $\$ 1.4$ billion, while the average analyst sample firm size is \$2.9 billion.

It is also possible that the analyst model captures only a portion of the misvaluation measured by the perfect foresight model. In our framework, misvaluation comes from 2 sources: the manager's private information about future firm cash flows that differs from the market's perception, and the market's irrationality regarding the value of the firm's future cash flows. The perfect foresight model could capture both sources of misvaluation, whereas the analyst model presumably only captures the latter. Therefore, we might expect the analyst model to be a weaker predictor of misvaluation. 


\section{TABLE 7}

\section{Speed of Adjustment Regressions Using Ex Post Earnings Value-to-Price Ratio for the Analyst Subset of Firms}

Table 7 presents the speed of adjustment estimates $(\lambda)$ obtained from separate regressions of the following equation for subsamples of firm years based on whether the firm is over- or underlevered and over- or undervalued:

(1)

$$
\mathrm{DR}_{t+1}-\mathrm{DR}_{t}=\lambda\left[\mathrm{TL}_{t+1}-\mathrm{DR}_{t}\right]+e_{t+1}
$$

where DR $\mathrm{Dt}_{t+1}$ is the debt-to-assets ratio in period $t+1$ and $\mathrm{TL}_{t+1}$ is the target debt ratio in period $t+1$ obtained using the Fama and French (2002) and Blundell and Bond (1998) approaches for estimating the target book debt ratio (BDR) and target market debt ratio (MDR). Please see Section III.C for details. The distance $\left[\mathrm{TL}_{t+1}-\mathrm{DR}_{t}\right]$ is the total amount that the debt ratio must change to bring the firm back to its target debt ratio. The value-to-price (VP) ratio is computed using the perfect foresight model, but the sample is restricted to firms that have analyst forecast data, as in Table 6 . Panels $A$ and $B$ report results from the Fama and French targets using the MDR and BDR, respectively. Panels $C$ and $D$ report results from the Blundell and Bond targets using the MDR and BDR, respectively. The 1st and 2nd columns present the results for firm years with overvalued and undervalued equity, respectively. The 3 rd column presents the $t$-statistic ( $p$-value) for the difference between the coefficients in the first 2 columns. The $t$-statistics (in parentheses) for the adjustment speeds are corrected for heteroskedasticity and firm-level clustering. Regressions include unreported year dummy variables and firm fixed effects, and ${ }^{\star \star \star},{ }^{\star \star}$, and ${ }^{\star}$ indicate significance at the $1 \%, 5 \%$, and $10 \%$ levels, respectively.

$$
\begin{gathered}
\text { Overvalued } \\
(\mathrm{VP}<\text { median VP) }
\end{gathered}
$$

Panel A. MDRs Using Fama and French Targets

Overlevered (DISTANCE < 0)

Underlevered (DISTANCE >0

$0.5815^{\star \star \star}$

$0.2734^{\star \star \star}$

(10.59)

Panel B. BDRs Using Fama and French Targets

Overlevered (DISTANCE $<0$ )

Underlevered (DISTANCE >0)

$0.4368^{\star \star *}$

(14.09)

$0.3812^{\star \star \star}$

(14.37)

Panel C. MDRs Using Blundell and Bond Targets

Overlevered (DISTANCE < 0) $\quad 0.3172^{\text {*** }}$

Underlevered (DISTANCE > 0)

$0.1849^{\star \star \star}$

(7.88)

Panel D. BDRs Using Blundell and Bond Targets

Overlevered (DISTANCE < 0$) \quad 0.3442^{\star * *}$

Underlevered (DISTANCE $>0$ )

$$
\begin{aligned}
& n=3,605 \\
& n=7,000
\end{aligned}
$$

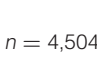

$n=6,101$

$n=4.732$

$n=5,873$

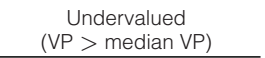

$(\mathrm{VP}>$ median VP)
Difference t-Stat ( $p$-value)

$$
\begin{aligned}
& 0.3703^{\text {*** }} \\
& \text { (11.09) } \\
& n=3,208 \\
& 3.74^{\star * *}
\end{aligned}
$$

$$
\begin{array}{llc}
0.2793^{\star * *} & & 3.37^{\star} \\
(8.35) & n=3,041 & (0.072) \\
0.3953^{\star * *} & & -0.3204 \\
(11.10) & n=3,439 & (0.749)
\end{array}
$$

\section{E. Randomized Data for the Equity Mispricing Dummy Variable}

We are, in effect, testing a joint hypothesis that we have correctly estimated the TL and the mispricing of the equity. Chang and Dasgupta (2009), among others, have found that target adjustment models are unable to reject alternative hypotheses. While our tests primarily focus on the differential in adjustment rates rather than the absolute level, our mispricing result may still be spurious. To this end, we use a simulation to show that our tests have the power to reject alternative hypotheses. In the spirit of the tests used by Chang and Dasgupta, we use a simulation that substitutes a randomly generated dummy variable (a coin toss is used to determine over- or undervaluation) for the actual valuation dummy variable used in Tables 5 and 6 . We replicate this simulation process 500 times and report the average coefficients, $t$-statistics, and $p$-values in Table 8 . On average, there is no significant difference between the speed of adjustment for under- and overvalued firms in the simulated sample, confirming that our results are not spurious. 
TABLE 8

Speed of Adjustment Regressions Using Randomized Data for the Equity Mispricing Dummy Variable

Table 8 presents the speed of adjustment estimates $(\lambda)$ obtained from separate regressions of the following equation for subsamples of firm years based on whether the firm is over- or underlevered and over- or undervalued:

$$
\mathrm{DR}_{t+1}-\mathrm{DR}_{t}=\lambda\left[\mathrm{TL}_{t+1}-\mathrm{DR}_{t}\right]+e_{t+1}
$$

where $\mathrm{DR}_{t+1}$ is the debt-to-assets ratio in period $t+1$ and $\mathrm{TL}_{t+1}$ is the target debt ratio in period $t+1$ obtained using the Fama and French (2002) and Blundell and Bond (1998) approaches for estimating the target book debt ratio (BDR) and target market debt ratio (MDR). Please see Section III.C for details. The distance $\left[\mathrm{TL}_{t+1}-\mathrm{DR} \mathrm{R}_{t}\right]$ is the total amount that the debt ratio must change to bring the firm back to its target debt ratio. VP is the value-to-price ratio computed by a coin toss ( $50 \%$ chance). The regressions are run 500 times, and average coefficients are reported. The overall sample size for each panel is 46,666 evenly distributed between over- and undervalued firms. The proportions of over- and underlevered firms are, on average, the same as in Table 5. Panels $A$ and $B$ report results from the Fama and French targets using the MDR and $\mathrm{BDR}$, respectively. Panels $\mathrm{C}$ and $\mathrm{D}$ report results from the Blundell and Bond targets using the MDR and BDR, respectively. The 1 st and 2nd columns present the results for firm years with overvalued and undervalued equity, respectively. The 3rd column presents the $t$-statistic ( $p$-value) for the difference between the coefficients in the first 2 columns. The $t$-statistics (in parentheses) for the adjustment speeds are corrected for heteroskedasticity and firm-level clustering and firm fixed effects. Regressions include unreported year dummy variables, and ${ }^{\star \star \star},{ }^{\star \star}$, and * indicate significance at the $1 \%, 5 \%$, and $10 \%$ levels, respectively.

\begin{tabular}{ccc}
$\begin{array}{c}\text { Overvalued } \\
(\mathrm{VP}<\text { median VP })\end{array}$ & $\begin{array}{c}\text { Undervalued } \\
(\mathrm{VP}>\text { median VP })\end{array}$ & $\begin{array}{c}\text { Difference } \\
t \text {-Stat }(p \text {-value })\end{array}$ \\
\cline { 2 - 3 } 0.4140 & 0.4310 & $-0.80(0.372)$ \\
0.3019 & 0.3116 & $-0.48(0.404)$ \\
0.3418 & & \\
0.3541 & 0.3550 & $-0.74(0.353)$ \\
& 0.3637 & $-0.51(0.420)$ \\
0.3078 & & $-0.73(0.389)$ \\
0.2263 & 0.3181 & $-0.53(0.387)$ \\
0.2745 & 0.2347 & $-0.67(0.362)$ \\
0.2830 & & $-0.35(0.368)$ \\
\hline
\end{tabular}

\section{F. Cash Flow, Mispricing, and Adjustment Speeds}

Faulkender et al. (2009) find that the level of free cash flow (FCF) impacts the firm's adjustment speed. Firms with either very low (negative) or very high (positive) FCF are more likely to take bolder steps to deal with their cash flow positions. Conditioned on this evidence, we expect firms that are above their TL, with negative cash flow, and whose equity is overvalued (these are the top left quadrant of Table 1) will be most likely to issue equity. In essence, "all the planets are aligned"; the firm is overlevered and therefore needs to increase equity; cash flow is negative, so capital must be raised; and equity is overvalued, and the cost of equity is cheap. We expect this type of firm to adjust rapidly, relative to a firm that has a similar leverage and cash flow position, whose equity is undervalued.

Likewise, a firm that is underlevered, with positive cash flow, and has undervalued equity (the bottom right quadrant of Table 1) will adjust toward its target more rapidly than a similarly situated firm with overvalued equity. Again, for such a firm, the "planets are aligned," and thus the firm will move toward its debt target more rapidly.

We test for these effects by segregating the sample based upon FCF. We use the Faulkender et al. (2009) method to compute cash flow, where $\mathrm{FCF}_{t+1}=$ 
[operating income before depreciation ${ }_{t}-$ taxes $_{t}-$ capital expenditures $_{t}$ ]/book assets $_{t}$, and classify low cash flow firms as those in the lower quartile, while high cash flow firms are those in the upper quartile. ${ }^{16}$ We repeat the tests using Faulkender et al.'s FCF1 (deduct interest expense) and FCF2 (deduct dividends) and using $33 \%$ and $66 \%$ cutoffs and find qualitatively similar results.

Panel A of Table 9 presents the tests for the Fama and French (2002) market debt targets. Panels B, C, and D repeat this analysis using the BDR (Fama and French targets), and the Blundell and Bond (1998) targets (both MDRs and BDRs),

\section{TABLE 9}

\section{Test of the Difference between Adjustment Speeds for Low and High Cash Flow Firms}

Table 9 presents the speed of adjustment estimates $(\lambda)$ obtained from separate regressions of the following equation for subsamples of firm years based on whether the firm is over- or underlevered and over- or undervalued and whether the firm has high or low cash flow:

$$
\mathrm{DR}_{t+1}-\mathrm{DR}_{t}=\lambda\left[\mathrm{TL}_{t+1}-\mathrm{DR} t\right]+e_{t+1}
$$

where $\mathrm{DR}_{t+1}$ is the debt-to-assets ratio in period $t+1$ and $\mathrm{TL}_{t+1}$ is the target debt ratio in period $t+1$ obtained using the Fama and French (2002) and Blundell and Bond (1998) approaches for estimating the target book debt ratio (BDR) and target market debt ratio (MDR). Please see Section III.C for details. The distance $\left[\mathrm{TL}_{t+1}-\mathrm{DR}_{t}\right]$ is the total amount that the debt ratio must change to bring the firm back to its target debt ratio. The overall sample size is 46,666 . Panels $A$ and $B$ report results from the Fama and French targets using the MDR and BDR, respectively. Panels $C$ and D report results from the Blundell and Bond targets using the MDR and BDR, respectively. The 1st and 2nd columns present the results for firm years with overvalued and undervalued equity, respectively. The $3 r d$ column presents the $t$-statistic $(p-$ value) for the difference between the coefficients in the first 2 columns. The value-to-price (VP) ratio is computed using the perfect foresight residual income model. The $t$-statistics (in parentheses) for the adjustment speeds are corrected for heteroskedasticity and firm-level clustering. Regressions include unreported year dummy variables and firm fixed effects, and ${ }^{* * *},{ }^{* *}$, and ${ }^{*}$ indicate significance at the $1 \%, 5 \%$, and $10 \%$ levels, respectively.

\begin{tabular}{|c|c|c|c|c|c|}
\hline \multicolumn{3}{|c|}{$\begin{array}{l}\text { Low Cash Flow } \\
\text { (lower quartile) }\end{array}$} & \multicolumn{3}{|c|}{$\begin{array}{l}\text { High Cash Flow } \\
\text { (upper quartile) }\end{array}$} \\
\hline $\begin{array}{c}\text { Overvalued } \\
(\mathrm{VP}<\text { median VP) }\end{array}$ & $\begin{array}{c}\text { Undervalued } \\
(\mathrm{VP}>\text { median VP) }\end{array}$ & $\begin{array}{c}\text { Difference } \\
t \text {-Stat } \\
\text { (p-value) }\end{array}$ & $\begin{array}{c}\text { Overvalued } \\
(\mathrm{VP}<\text { median VP) }\end{array}$ & $\begin{array}{c}\text { Undervalued } \\
(\mathrm{VP}>\text { median VP) }\end{array}$ & $\begin{array}{c}\text { Difference } \\
t \text {-Stat } \\
\text { ( } p \text {-value })\end{array}$ \\
\hline
\end{tabular}

Panel A. MDRs Using Fama and French Targets

\begin{tabular}{|c|c|c|c|c|c|c|}
\hline $\begin{array}{l}\text { Overlevered } \\
\quad(\text { DISTANCE < 0) }\end{array}$ & $\begin{array}{l}0.7338^{\star \star \star} \\
(13.20)\end{array}$ & $\begin{array}{l}0.5427^{\star \star *} \\
(10.48)\end{array}$ & $\begin{array}{l}2.50^{\star \star} \\
(0.012)\end{array}$ & $\begin{array}{l}0.4755^{\star \star \star} \\
(6.94)\end{array}$ & $\begin{array}{l}0.2858^{\star \star \star} \\
(6.61)\end{array}$ & $\begin{array}{l}2.42^{\star \star} \\
(0.015)\end{array}$ \\
\hline $\begin{array}{l}\text { Underlevered } \\
\quad(\text { DISTANCE > 0) }\end{array}$ & $\begin{array}{l}0.2877^{\star \star \star} \\
(7.60)\end{array}$ & $\begin{array}{l}0.5106^{* * *} \\
(8.70)\end{array}$ & $\begin{array}{c}-3.24^{* \star *} \\
(0.001)\end{array}$ & $\begin{array}{l}0.2084^{\star \star \star} \\
(5.21)\end{array}$ & $\begin{array}{l}0.5096^{\star \star \star} \\
(12.70)\end{array}$ & $\begin{array}{l}-5.18^{* * *} \\
(<0.001)\end{array}$ \\
\hline \multicolumn{7}{|c|}{ Panel B. BDRs Using Fama and French Targets } \\
\hline $\begin{array}{l}\text { Overlevered } \\
\quad(\text { DISTANCE < 0) }\end{array}$ & $\begin{array}{l}0.6373^{\star \star \star} \\
(13.62)\end{array}$ & $\begin{array}{l}0.5072^{* * *} \\
(9.11)\end{array}$ & $\begin{array}{c}1.79^{\star} \\
(0.073)\end{array}$ & $\begin{array}{l}0.4092^{\star \star *} \\
(9.66)\end{array}$ & $\begin{array}{l}0.2276^{\star \star \star} \\
(5.95)\end{array}$ & $\begin{array}{l}3.17^{\star \star \star} \\
(0.001)\end{array}$ \\
\hline $\begin{array}{l}\text { Underlevered } \\
\quad(\text { DISTANCE > 0) }\end{array}$ & $\begin{array}{l}0.4139^{\star \star \star} \\
(11.02)\end{array}$ & $\begin{array}{l}0.5237^{* \star *} \\
(11.65)\end{array}$ & $\begin{array}{l}-1.83^{*} \\
(0.068)\end{array}$ & $\begin{array}{l}0.3942^{* * *} \\
(9.49)\end{array}$ & $\begin{array}{l}0.5156^{\star \star \star} \\
(12.37)\end{array}$ & $\begin{array}{l}-2.05^{\star \star} \\
(0.040)\end{array}$ \\
\hline \multicolumn{7}{|c|}{ Panel C. MDRs Using Blundell and Bond Targets } \\
\hline $\begin{array}{l}\text { Overlevered } \\
\quad(\text { DISTANCE < 0) }\end{array}$ & $\begin{array}{l}0.4602^{\star \star \star} \\
(7.65)\end{array}$ & $\begin{array}{l}0.3720^{\star * *} \\
(9.06)\end{array}$ & $\begin{array}{l}1.25 \\
(0.210)\end{array}$ & $\begin{array}{l}0.3683^{* \star *} \\
(9.20)\end{array}$ & $\begin{array}{l}0.3513^{\star * *} \\
(11.70)\end{array}$ & $\begin{array}{l}0.35 \\
(0.730)\end{array}$ \\
\hline $\begin{array}{l}\text { Underlevered } \\
\qquad(\text { DISTANCE >0) }\end{array}$ & $\begin{array}{l}0.2011^{\star \star \star} \\
(8.63)\end{array}$ & $\begin{array}{l}0.4021^{* \star *} \\
(9.56)\end{array}$ & $\begin{array}{l}-4.43 \\
(<0.001)\end{array}$ & $\begin{array}{l}0.0802^{\star \star} \\
(2.18)\end{array}$ & $\begin{array}{l}0.2417^{\star \star \star} \\
(5.43)\end{array}$ & $\begin{array}{l}-2.79^{\star \star \star} \\
(0.005)\end{array}$ \\
\hline \multicolumn{7}{|c|}{$\underline{\text { Panel D. BDRs Using Blundell and Bond Targets }}$} \\
\hline $\begin{array}{l}\text { Overlevered } \\
\quad(\text { DISTANCE < 0) }\end{array}$ & $\begin{array}{l}0.5730^{\star \star \star} \\
(7.97)\end{array}$ & $\begin{array}{l}0.3899^{* * *} \\
(6.61)\end{array}$ & $\begin{array}{l}1.94^{\star} \\
(0.052)\end{array}$ & $\begin{array}{l}0.3376^{\star \star \star} \\
(11.71)\end{array}$ & $\begin{array}{l}0.2684^{\star \star \star} \\
(9.26)\end{array}$ & $\begin{array}{c}1.69^{*} \\
(0.092)\end{array}$ \\
\hline $\begin{array}{l}\text { Underlevered } \\
\qquad(\text { DISTANCE > 0) }\end{array}$ & $\begin{array}{l}0.2916^{\star \star \star} \\
(12.04)\end{array}$ & $\begin{array}{l}0.4066^{* * *} \\
(11.41)\end{array}$ & $\begin{array}{c}-2.72^{* \star \star} \\
(0.007)\end{array}$ & $\begin{array}{l}0.3954^{\star \star *} \\
(7.41)\end{array}$ & $\begin{array}{l}0.3283^{* \star \star} \\
(5.86)\end{array}$ & $\begin{array}{l}0.87 \\
(0.386)\end{array}$ \\
\hline
\end{tabular}

\footnotetext{
${ }^{16}$ Faulkender et al. (2009) use $15 \%$ and $85 \%$ cutoffs for their cash flow variables; however, we find that such cutoffs significantly reduce our sample size. As we are already cutting the sample by TL and valuation, further cuts result in relatively fewer firms in each quadrant.
} 
respectively. Within each panel we present the quadrant regressions for the low cash flow firms (i.e., lower quartile) on the left-hand side of the table, and the quadrant regressions for the high cash flow firms (i.e., upper quartile) on the righthand side of the table.

Before we examine the effects of cash flow on a firm's speed of adjustment when conditions are best suited for equity issuance, we check whether the data continue to support our basic hypothesis. The results show that the expected differential in adjustment speeds based on leverage and valuation are still present after bifurcating the data by cash flow. For example, in Panel A of Table 9, within the low cash flow group, overlevered and overvalued firms adjust more rapidly than their undervalued counterparts. The difference in speeds is significant, with a $t$-statistic of 2.50. Furthermore, the same pattern persists for the high cash flow firms. For the high cash flow firms, the overlevered and overvalued firms adjust more rapidly than overlevered and undervalued firms, with a significant difference and a $t$-statistic of 2.42 .

Turning now to the effects of cash flow on the speed of adjustment when the incentives to issue equity are aligned (i.e., overlevered, overvalued firms that have low cash flow), the speed of adjustment is 0.7338 , implying that these firms adjust back to their TL in less than 1.4 years. On the other hand, the similarly valued and levered high cash flow firms adjust at a slower rate of 0.4755 and require 2.1 years (this difference is significant at the $1 \%$ level). The corollary does not hold for the firms that ought to be repurchasers, (underlevered and undervalued firms with high cash flows), as the difference in adjustment speeds between low (0.5106) and high (0.5096) cash flow firms is insignificant.

Panels B, C, and D of Table 9 repeat this analysis using the BDR (Fama and French (2002) targets), and the Blundell and Bond (1998) targets (both MDRs and BDRs), respectively, with qualitatively similar results. Overall these results corroborate our primary findings and confirm that the market timing effect is independent of the cash flow effect. Furthermore, for equity issuers, the cash flow position of the firm increases the valuation effect on the rate of adjustment in a predictable manner.

\section{G. Growth Opportunities and Mispricing}

Book-to-market ratio can be decomposed into book-to-value and value-tomarket (the latter we refer to as VP). Theoretically, this decomposition should completely separate growth options from equity mispricing. However, the empirical implementation may induce some systemic error. Therefore, to ensure that it is indeed mispricing and not growth opportunities that are driving the results, we control for book-to-market ratios by dividing the sample into high (top quartile) and low (bottom quartile) book-to-market subsamples. We then reestimate the adjustment speed regressions on these subsamples and report the results in Table 10 (the table is formatted similar to Table 9 except the first 3 columns correspond to low book-to-market and the last 3 columns correspond to high book-to-market quartiles).

If VP were just measuring growth options, then there should be no significant difference between the low VP (i.e., overvalued) firms and the high VP 
TABLE 10

Test of the Difference between Adjustment Speeds for Low and High Book-to-Market Firms

Table 10 presents the speed of adjustment estimates $(\lambda)$ obtained from separate regressions of the following equation for subsamples of firm years based on whether the firm is over- or underlevered and over- or undervalued and whether the firm has high or low book-to-market:

$$
\mathrm{DR}_{t+1}-\mathrm{DR}_{t}=\lambda\left[\mathrm{TL}_{t+1}-\mathrm{DR}_{t}\right]+e_{t+1}
$$

where $\mathrm{DR}_{t+1}$ is the debt-to-assets ratio in period $t+1$ and $\mathrm{TL}_{t+1}$ is the target debt ratio in period $t+1$ obtained using the Fama and French (2002) and Blundell and Bond (1998) approaches for estimating the target book debt ratio (BDR) and target market debt ratio (MDR). Please see Section III.C for details. The distance $\left[\mathrm{TL}_{t+1}-\mathrm{DR}_{t}\right]$ is the total amount that the debt ratio must change to bring the firm back to its target debt ratio. The overall sample size is 46,666 . Panels $A$ and $B$ report results from the Fama and French targets using the MDR and BDR, respectively. Panels $C$ and D report results from the Blundell and Bond targets using the MDR and BDR, respectively. The 1st and 2nd columns present the results for firm years with overvalued and undervalued equity, respectively. The $3 r d$ column presents the $t$-statistic $(p-$ value) for the difference between the coefficients in the first 2 columns. The value-to-price (VP) ratio is computed using the perfect foresight residual income model. The $t$-statistics (in parentheses) for the adjustment speeds are corrected for heteroskedasticity and firm-level clustering. Regressions include unreported year dummy variables and firm fixed effects, and ${ }^{* \star *},{ }^{* *}$, and ${ }^{*}$ indicate significance at the $1 \%, 5 \%$, and $10 \%$ levels, respectively.

\begin{tabular}{|c|c|c|c|c|c|}
\hline \multicolumn{3}{|c|}{$\begin{array}{l}\text { Low Book-to-Market } \\
\text { (lower quartile) }\end{array}$} & \multicolumn{3}{|c|}{$\begin{array}{l}\text { High Book-to-Market } \\
\text { (upper quartile) }\end{array}$} \\
\hline $\begin{array}{c}\text { Overvalued } \\
(\mathrm{VP}<\text { median VP) }\end{array}$ & $\begin{array}{c}\text { Undervalued } \\
(\mathrm{VP}>\text { median VP) }\end{array}$ & $\begin{array}{c}\text { Difference } \\
t \text {-Stat } \\
\text { ( } p \text {-value) }\end{array}$ & $\begin{array}{c}\text { Overvalued } \\
(\mathrm{VP}<\text { median VP) }\end{array}$ & $\begin{array}{c}\text { Undervalued } \\
(\text { VP }>\text { median VP) }\end{array}$ & $\begin{array}{c}\text { Difference } \\
t \text {-Stat } \\
\text { (p-value) }\end{array}$ \\
\hline
\end{tabular}

Panel A. MDRs Using Fama and French Targets

\begin{tabular}{|c|c|c|c|c|c|c|}
\hline $\begin{array}{l}\text { Overlevered } \\
\quad(\text { DISTANCE < } 0)\end{array}$ & $\begin{array}{l}0.5073^{\star \star \star} \\
(11.98)\end{array}$ & $\begin{array}{l}0.4075^{\star \star \star} \\
(7.86)\end{array}$ & $\begin{array}{l}1.18 \\
(0.236)\end{array}$ & $\begin{array}{l}0.5491^{\star \star \star} \\
(12.25)\end{array}$ & $\begin{array}{l}0.3490^{\star \star \star} \\
(20.24)\end{array}$ & $(<0.001)$ \\
\hline $\begin{array}{l}\text { Underlevered } \\
\quad(\text { DISTANCE > }>0)\end{array}$ & $\begin{array}{l}0.2103^{* \star \star} \\
(11.03)\end{array}$ & $\begin{array}{l}0.3884^{\star \star \star} \\
(10.88)\end{array}$ & $\begin{array}{l}-4.31^{* \star \star} \\
(<0.001)\end{array}$ & $\begin{array}{l}0.4346^{* * *} \\
(7.18)\end{array}$ & $\begin{array}{l}0.4057^{\star \star \star} \\
(16.57)\end{array}$ & $\begin{array}{l}0.52 \\
(0.603)\end{array}$ \\
\hline \multicolumn{7}{|c|}{ Panel B. BDRs Using Fama and French Targets } \\
\hline $\begin{array}{l}\text { Overlevered } \\
\quad(\text { DISTANCE < } 0)\end{array}$ & $\begin{array}{l}0.4875^{\star \star \star} \\
(21.67)\end{array}$ & $\begin{array}{l}0.3245^{* * *} \\
(7.52)\end{array}$ & $\begin{array}{l}3.44^{\star \star \star} \\
(<0.001)\end{array}$ & $\begin{array}{l}0.4476^{\star \star \star} \\
(11.13)\end{array}$ & $\begin{array}{l}0.3091^{\text {*** }} \\
(16.71)\end{array}$ & $\begin{array}{l}3.44^{* * *} \\
(<0.001)\end{array}$ \\
\hline $\begin{array}{l}\text { Underlevered } \\
\quad(\text { DISTANCE > 0) }\end{array}$ & $\begin{array}{l}0.3788^{\star \star \star} \\
(18.09)\end{array}$ & $\begin{array}{l}0.4822^{\star \star \star} \\
(10.47)\end{array}$ & $\begin{array}{r}-2.16^{\star *} \\
(0.031)\end{array}$ & $\begin{array}{l}0.4201^{* * *} \\
(9.09)\end{array}$ & $\begin{array}{l}0.4058^{\star \star \star} \\
(21.61)\end{array}$ & $\begin{array}{l}0.34 \\
(0.732)\end{array}$ \\
\hline \multicolumn{7}{|c|}{ Panel C. MDRs Using Blundell and Bond Targets } \\
\hline $\begin{array}{l}\text { Overlevered } \\
\quad(\text { DISTANCE < < })\end{array}$ & $\begin{array}{l}0.2755^{\star \star \star} \\
(12.74)\end{array}$ & $\begin{array}{l}0.2544^{\star \star *} \\
(6.72)\end{array}$ & $\begin{array}{l}0.49 \\
(0.624)\end{array}$ & $\begin{array}{l}0.4224^{\star \star \star} \\
(12.82)\end{array}$ & $\begin{array}{l}0.3076^{\star \star \star} \\
(23.72)\end{array}$ & $\begin{array}{l}3.77^{* \star *} \\
(<0.001)\end{array}$ \\
\hline $\begin{array}{l}\text { Underlevered } \\
\quad(\text { DISTANCE > 0) }\end{array}$ & $\begin{array}{l}0.1476^{\star \star \star} \\
(10.14)\end{array}$ & $\begin{array}{l}0.2239^{\star * *} \\
(7.89)\end{array}$ & $\begin{array}{l}-2.33^{\star \star} \\
(0.02)\end{array}$ & $\begin{array}{l}0.3080^{* * *} \\
(5.13)\end{array}$ & $\begin{array}{l}0.2946^{\star \star \star} \\
(13.42)\end{array}$ & $\begin{array}{l}0.26 \\
(0.800)\end{array}$ \\
\hline \multicolumn{7}{|c|}{ Panel D. BDRs using Blundell and Bond Targets } \\
\hline $\begin{array}{l}\text { Overlevered } \\
\quad(\text { DISTANCE < } 0)\end{array}$ & $\begin{array}{l}0.3721^{\star \star \star} \\
(19.57)\end{array}$ & $\begin{array}{l}0.2716^{\star * *} \\
(7.32)\end{array}$ & $\begin{array}{l}2.50 * \star \\
(0.012)\end{array}$ & $\begin{array}{l}0.3618^{\star \star \star} \\
(9.08)\end{array}$ & $\begin{array}{l}0.2895^{\text {** }} \\
(19.82)\end{array}$ & $\begin{array}{r}2.09 * * \\
(0.037)\end{array}$ \\
\hline $\begin{array}{l}\text { Underlevered } \\
\quad(\text { DISTANCE >0) }\end{array}$ & $\begin{array}{l}0.2991^{* \star \star} \\
(16.08)\end{array}$ & $\begin{array}{l}0.4147^{\star \star \star} \\
(10.63)\end{array}$ & $\begin{array}{l}-2.74^{* * *} \\
(0.006)\end{array}$ & $\begin{array}{l}0.3281^{* * *} \\
(5.56)\end{array}$ & $\begin{array}{l}0.3212^{\star \star \star} \\
(14.99)\end{array}$ & $\begin{array}{l}0.13 \\
(0.894)\end{array}$ \\
\hline
\end{tabular}

(i.e., undervalued) firms. In Panel A of Table 10, for low book-to-market, overlevered firms, the overvalued firms adjust significantly faster than the undervalued firms. However, this difference is not significant. For the underlevered group, the undervalued firms adjust faster than the overvalued firms $(t$-statistic $=-4.31)$.

For the high book-to-market, overlevered firms, those that are overvalued firms adjust more rapidly than undervalued firms. However, for underlevered firms, the difference between over- and undervalued firms disappears. Panels B, $\mathrm{C}$, and $\mathrm{D}$ of Table 10 have qualitatively similar results. In sum, the results are broadly robust to controlling for book-to-market. Not surprisingly, in some cases the magnitudes of the differences in adjustment speeds are reduced, as our VP measure is a component of book-to-market (i.e., book-to-price) and the two are positively correlated. 


\section{H. Zero-Debt Firms}

In Table 11 we repeat our primary analysis and include firms with no longterm debt. In the preceding tests these firms were excluded on the premise that firms with no long-term debt may not pursue a TL policy and are therefore likely to remain zero-debt firms regardless of the economic incentives to do otherwise. ${ }^{17}$ Including the zero-debt firms will predominantly affect the underlevered portion of the sample, as they typically will be below their optimal target. However,

TABLE 11

Speed of Adjustment Regressions Including Zero-Debt Firms

Table 11 presents the speed of adjustment estimates $(\lambda)$ obtained from separate regressions of the following equation for subsamples of firm years based on whether the firm is over- or underlevered and over- or undervalued:

$$
\mathrm{DR}_{t+1}-\mathrm{DR}_{t}=\lambda\left[\mathrm{TL}_{t+1}-\mathrm{DR}_{t}\right]+e_{t+1},
$$

where $\mathrm{DR}_{t+1}$ is the debt-to-assets ratio in period $t+1$ and $\mathrm{TL}_{t+1}$ is the target debt ratio in period $t+1$ obtained using the Fama and French (2002) and Blundell and Bond (1998) approaches for estimating the target book debt ratio (BDR) and target market debt ratio (MDR). Please see Section III.C for details. The distance $\left[\mathrm{TL}_{t+1}-\mathrm{DR}_{t}\right]$ is the total amount that the debt ratio must change to bring the firm back to its target debt ratio. The adjustment speed reported is the coefficient estimate on the DISTANCE in equation (1). This table includes the 8,112 firms that previously were deleted because they had zero-debt levels. Panels A and B report results from the Fama and French targets using the MDR and BDR, respectively. Panels $C$ and $D$ report results from the Blundell and Bond targets using the MDR and BDR, respectively. The 1st and 2 nd columns present the results for firm years with overvalued and undervalued equity, respectively. The 3rd column presents the $t$-statistic ( $p$-value) for the difference between the coefficients in the first 2 columns. Zero-debt firms are included in the sample for both the estimation of the TL and the speed of adjustments. The value-to-price (VP) ratio is computed using the perfect foresight residual income model. The $t$-statistics (in parentheses) for the adjustment speeds are corrected for heteroskedasticity and firm-level clustering. Regressions include unreported year dummy variables and firm fixed effects, and ${ }^{* \star *},{ }^{* \star}$, and * indicate significance at the $1 \%, 5 \%$, and $10 \%$ levels, respectively.

\begin{tabular}{ccc}
$\begin{array}{c}\text { Overvalued } \\
(\mathrm{VP}<\text { median VP) }\end{array}$ & $\begin{array}{c}\text { Undervalued } \\
(\mathrm{VP}>\text { median VP) }\end{array}$ & $\underline{t \text {-Stat }(p \text {-value })}$ \\
\hline
\end{tabular}

Panel A. MDRs Using Fama and French Targets

$\begin{array}{lc}\text { Overlevered (DISTANCE }<0) & 0.5068^{\star \star \star} \\ \text { Underlevered (DISTANCE }>0) & (20.95) \\ & 0.1959^{* \star \star} \\ \text { Panel B. BDRs Using Fama and French Targets }\end{array}$

$\begin{array}{lc}0.3607^{\star \star \star} & 5.52^{\star \star *} \\ (24.95) & (<0.001) \\ 0.3819^{\star \star \star} & -7.93^{\star \star \star} \\ (22.51) & (<0.001)\end{array}$

\begin{tabular}{lc}
\hline Overlevered (DISTANCE $<0)$ & $0.4489^{* \star \star}$ \\
Underlevered (DISTANCE $>0)$ & $(25.40)$ \\
$0.2175^{\star \star \star}$ & $(14.58)$
\end{tabular}

$\begin{array}{lr}0.3163^{\star \star \star} & 5.60^{\star \star *} \\ (19.92) & (<0.001) \\ 0.3907^{\star \star \star} & -8.08^{\star \star \star} \\ (25.39) & (<0.001)\end{array}$

Panel C. MDRs Using Blundell and Bond Targets

\begin{tabular}{lc}
\hline Overlevered (DISTANCE $<0)$ & $0.3128^{\star * \star}$ \\
Underlevered (DISTANCE $>0)$ & $(18.93)$ \\
& $0.1170^{\star * \star}$ \\
& $(9.61)$
\end{tabular}

$\begin{array}{lc}0.3008^{\star \star \star} & 0.62 \\ (27.03) & (0.533) \\ 0.2410^{\star \star \star} & -6.37^{\star \star \star} \\ (15.71) & (<0.001)\end{array}$

Panel D. BDRs Using Blundell and Bond Targets

$\begin{array}{lc}\text { Overlevered (DISTANCE < } & 0.3549^{* \star *} \\ \text { Underlevered (DISTANCE > }) & (24.49) \\ 0.2418^{* \star *} & (16.62)\end{array}$

$0.2713^{\star * *}$
$(22.08)$
$0.3057^{\star * *}$
$(20.36)$

\footnotetext{
${ }^{17}$ Byoun et al. (2008) note that debt-free firms seem to behave in a manner that "is contrary to value maximization." Further, many of these firms remain debt free for extended periods. Since we constrain the predicted target to be between 0 and 1 , all debt-free firms will be classified as underlevered. If the valuation measure is distributed similarly across these firms as in the levered firms, the zero-debt firms will reduce the rate of adjustment for both over- and undervalued firms, and the primary impact will be an increase in the standard error.
} 
depending upon the estimation approach (as discussed in Section III.C), some targets are less than 0 , and this would cause a small fraction of the zero-debt firms to be classified as overlevered. Additionally, since the target estimates use the full sample, inclusion of the zero-debt firms may have an impact on the overlevered sample. The inclusion of the zero long-term debt firms adds 8,112 observations to the analysis.

The results in Table 11 confirm our expectations. The overall speed of adjustment for the underlevered firms is lower than in the primary analysis. Given that many zero-debt firms rarely if ever add debt to their balance sheet, this is not surprising (i.e., many of these firms will have a zero-adjustment rate). However, despite the inclusion of zero-debt firms, for both underlevered and overlevered firms, the primary valuation result continues to hold, in some cases more strongly than in the earlier analysis.

\section{Conclusion}

We hypothesize that equity mispricing will impact the firm's rate of adjustment toward a TL. We expect to find that firms that are above their TL (i.e., firms that need to issue equity and/or repurchase debt) and whose equity is overpriced will adjust more rapidly toward their target than firms with underpriced equity. They will do so by issuing overvalued equity. Correspondingly, firms that are below their TL (i.e., firms that need to issue debt and/or repurchase equity) and whose equity is overpriced will adjust more slowly toward their target than firms with underpriced equity. In this case, the firms with underpriced equity will more aggressively repurchase shares.

The results of our empirical tests support our hypothesis. Under- versus overvalued firms adjust their leverage at significantly different rates. For example, in Panel A of Table 5, using the Fama and French (2002) targets and market leverage, overvalued firms adjust to their target in about 1.9 years, while undervalued firms take about 3 years. Our results are robust to different methods of measuring equity mispricing and modeling TL, alternative definitions of leverage, alternative time periods, including zero-debt firms, and adding controls for growth options and cash flow status.

The effect of equity mispricing on adjustment speeds becomes even more important when the firm's cash flow position is considered. In particular, firms with overvalued equity that need to raise capital and are also overlevered adjust more rapidly to their target than those firms that do not have cash flow shortfalls. Our findings are consistent with equity mispricing being an important capital structure adjustment cost.

\section{References}

Alti, A. "How Persistent Is the Impact of Market Timing on Capital Structure?" Journal of Finance, 61 (2006), 1681-1710.

Baker, M., and J. Wurgler. "Market Timing and Capital Structure.” Journal of Finance, 57 (2002), $1-32$.

Blundell, R., and S. Bond. "Initial Conditions and Moment Restrictions in Dynamic Panel Data Models." Journal of Econometrics, 87 (1998), 115-143. 
Butler, A. W.; J. Cornaggia; G. Grullon; and J. P. Weston. "Corporate Financing Decisions, Managerial Market Timing, and Real Investment.” Journal of Financial Economics, 101 (2011), 666-683.

Byoun, S. "How and When Do Firms Adjust Their Capital Structures toward Targets?" Journal of Finance, 63 (2008), 3069-3096.

Chang, X., and S. Dasgupta. "Target Behavior and Financing: How Conclusive Is the Evidence?" Journal of Finance, 64 (2009), 1767-1796.

Chen, L., and X. Zhao. "Mechanical Mean Reversion of Leverage Ratios." Economics Letters, 95 (2007), 223-229.

D'Mello, R., and P. K. Shroff. "Equity Undervaluation and Decisions Related to Repurchase Tender Offers: An Empirical Investigation.” Journal of Finance, 55 (2000), 2399-2425.

Dong, M.; D. Hirshleifer; S. Richardson; and S. H. Teoh. "Does Investor Misvaluation Drive the Takeover Market?" Journal of Finance, 61 (2006), 725-762.

Elliott, W. B.; J. Koëter-Kant; and R. S. Warr. “A Valuation-Based Test of Market Timing.” Journal of Corporate Finance, 13 (2007), 122-128.

Elliott, W. B.; J. Koëter-Kant; and R. S. Warr. "Market Timing and the Debt-Equity Choice." Journal of Financial Intermediation, 17 (2008), 175-197.

Fama, E. F., and K. R. French. "Industry Costs of Equity.” Journal of Financial Economics, 43 (1997), $153-193$.

Fama, E. F., and K. R. French. "Testing the Trade-Off and Pecking Order Predictions about Dividends and Debt." Review of Financial Studies, 15 (2002), 1-33.

Fama, E. F., and J. D. MacBeth. "Risk, Return, and Equilibrium: Empirical Tests." Journal of Political Economy, 81 (1973), 607-636.

Faulkender, M.; M. Flannery; K. Hankins; and J. Smith. "Are Adjustment Costs Impeding Realization of Target Capital Structure?” Working Paper, Washington University (2009).

Flannery, M., and K. Hankins. "A Theory of Capital Structure Adjustment Speed." Working Paper, University of Florida (2007).

Flannery, M. J., and K. P. Rangan. "Partial Adjustment toward Target Capital Structures.” Journal of Financial Economics, 79 (2006), 469-506.

Frankel, R., and C. M. C. Lee. "Accounting Valuation, Market Expectation, and Cross-Sectional Stock Returns." Journal of Accounting and Economics, 25 (1998), 283-319.

Graham, J. R., and C. R. Harvey. "The Theory and Practice of Corporate Finance: Evidence from the Field.” Journal of Financial Economics, 60 (2001), 187-243.

Hovakimian, A. "Are Observed Capital Structures Determined by Equity Market Timing?” Journal of Financial and Quantitative Analysis, 41 (2006), 221-243.

Hovakimian, A., and G. Li. "In Search of Conclusive Evidence: How to Test for Adjustment to Target Capital Structure." Journal of Corporate Finance, 17 (2011), 33-44.

Hovakimian, A.; T. Opler; and S. Titman. "The Debt-Equity Choice.” Journal of Financial and Quantitative Analysis, 36 (2001), 1-24.

Huang, R., and J. R. Ritter. "Testing Theories of Capital Structure and Estimating the Speed of Adjustment.” Journal of Financial and Quantitative Analysis, 44 (2009), 237-271.

Jalilvand, A., and R. S. Harris. "Corporate Behavior in Adjusting to Capital Structure and Dividend Targets: An Econometric Study." Journal of Finance, 39 (1984), 127-145.

Korteweg, A. "The Net Benefits to Leverage.” Journal of Finance, 65 (2010), 2137-2170.

Kothari, S. P., and J. Shanken. "Book-to-Market, Dividend Yield, and Expected Market Returns: A Time-Series Analysis.” Journal of Financial Economics, 44 (1997), 169-203.

La Porta, R. "Expectations and the Cross-Section of Stock Returns." Journal of Finance, 51 (1996), 1715-1742.

Leary, M. T., and M. R. Roberts. "Do Firms Rebalance Their Capital Structures?” Journal of Finance, 60 (2005), 2575-2619.

Lee, C. M. C.; J. Myers; and B. Swaminathan. "What Is the Intrinsic Value of the Dow?" Journal of Finance, 54 (1999), 1693-1741.

Lemmon, M. L.; M. R. Roberts; and J. F. Zender. "Back to the Beginning: Persistence and the CrossSection of Corporate Capital Structure." Journal of Finance, 63 (2008), 1575-1608.

Myers, S. C. “The Capital Structure Puzzle.” Journal of Finance, 39 (1984), 575-592.

Ohlson, J. A. "The Theory of Value and Earnings, and an Introduction to the Ball-Brown Analysis." Contemporary Accounting Research, 8 (1991), 1-19.

Ohlson, J. A. "Earnings, Book Values, and Dividends in Security Valuation." Contemporary Accounting Research, 11 (1995), 661-687.

Penman, S. H., and T. Sougiannis. "A Comparison of Dividend, Cash Flow, and Earnings Approaches to Equity Valuation.” Contemporary Accounting Research, 15 (1998), 343-383.

Rhodes-Kropf, M.; D. T. Robinson; and S. Viswanathan. "Valuation Waves and Merger Activity: The Empirical Evidence.” Journal of Financial Economics, 77 (2005), 561-603. 
616 Journal of Financial and Quantitative Analysis

Roberts, M. "The Dynamics of Capital Structure: An Empirical Analysis of a Partially Observable System.” Working Paper, Duke University (2001).

Shyam-Sunder, L., and S. C. Myers. "Testing Static Tradeoff Against Pecking Order Models of Capital Structure." Journal of Financial Economics, 51 (1999), 219-244.

Strebulaev, I. A. "Do Tests of Capital Structure Theory Mean What They Say?" Journal of Finance, 62 (2007), 1747-1787.

Welch, I. "Capital Structure and Stock Returns." Journal of Political Economy, 112 (2004), 106-132. 
Copyright of Journal of Financial \& Quantitative Analysis is the property of Cambridge University Press and its content may not be copied or emailed to multiple sites or posted to a listserv without the copyright holder's express written permission. However, users may print, download, or email articles for individual use. 